\title{
$\beta$-Adrenergic Receptors/Epac Signaling Increases the Size of the Readily Releasable Pool of Synaptic Vesicles Required for Parallel Fiber LTP
}

\author{
Ricardo Martín, ${ }^{1,2}$ Nuria García-Font, ${ }^{1,2}$ Alberto Samuel Suárez-Pinilla, ${ }^{1,2}$ David Bartolomé-Martín, ${ }^{1,2,3}$ \\ José Javier Ferrero, ${ }^{1,2,4}$ Rafael Luján, ${ }^{5}$ Magdalena Torres, ${ }^{1,2}$ and José Sánchez-Prieto ${ }^{1,2}$ \\ ${ }^{1}$ Departamento de Bioquímica y Biología Molecular, Facultad de Veterinaria, Instituto Universitario de Investigación en Neuroquímica, Universidad \\ Complutense, 28040 Madrid, Spain, ${ }^{2}$ Instituto de Investigación Sanitaria del Hospital Clínico San Carlos, 28040 Madrid, Spain, ${ }^{3}$ Departamento de \\ Ciencias Médicas Básicas (Fisiología), Universidad de La Laguna, 38072 La Laguna, Spain, ${ }^{4}$ Institute for Genomic Neuroscience, Columbia \\ University, New York, New York 10032, and ${ }^{5}$ Synaptic Structure Laboratory, Instituto de Investigación en Discapacidades Neurológicas (IDINE), \\ Departamento Ciencias Médicas, Facultad de Medicina, Universidad Castilla-La Mancha, 02008 Albacete, Spain
}

The second messenger cAMP is an important determinant of synaptic plasticity that is associated with enhanced neurotransmitter release. Long-term potentiation (LTP) at parallel fiber (PF)-Purkinje cell (PC) synapses depends on a $\mathrm{Ca}^{2+}$-induced increase in presynaptic cAMP that is mediated by $\mathrm{Ca}^{2+}$-sensitive adenylyl cyclases. However, the upstream signaling and the downstream targets of cAMP involved in these events remain poorly understood. It is unclear whether cAMP generated by $\beta$-adrenergic receptors ( $\beta$ ARs) is required for PF-PC LTP, although noradrenergic varicosities are apposed in PF-PC contacts. Guanine nucleotide exchange proteins directly activated by cAMP [Epac proteins (Epac 1-2)] are alternative cAMP targets to protein kinase A (PKA) and Epac2 is abundant in the cerebellum. However, whether Epac proteins participate in PF-PC LTP is not known. Immunoelectron microscopy demonstrated that $\beta$ ARs are expressed in PF boutons. Moreover, activation of these receptors through their agonist isoproterenol potentiated synaptic transmission in cerebellar slices from mice of either sex, an effect that was insensitive to the PKA inhibitors (H-89, KT270) but that was blocked by the Epac inhibitor ESI 05. Interestingly, prior activation of these $\beta$ ARs occluded PF-PC LTP, while the $\beta 1$ AR antagonist metoprolol blocked PF-PC LTP, which was also absent in Epac2 ${ }^{-/-}$mice. PF-PC LTP is associated with an increase in the size of the readily releasable pool (RRP) of synaptic vesicles, consistent with the isoproterenolinduced increase in vesicle docking in cerebellar slices. Thus, the $\beta$ AR-mediated modulation of the release machinery and the subsequent increase in the size of the RRP contributes to PF-PC LTP.

Key words: adrenergic receptors; Epac2 KO; neurotransmitter release; parallel fiber LTP; release machinery; RRP size

Significance Statement

G-protein-coupled receptors modulate the release machinery, causing long-lasting changes in synaptic transmission that influence synaptic plasticity. Nevertheless, the mechanisms underlying synaptic responses to $\beta$-adrenergic receptor ( $\beta$ AR) activation remain poorly understood. An increase in the number of synaptic vesicles primed for exocytosis accounts for the potentiation of neurotransmitter release driven by $\beta$ ARs. This effect is not mediated by the canonical protein kinase A pathway but rather, through direct activation of the guanine nucleotide exchange protein Epac by cAMP. Interestingly, this $\beta$ AR signaling via Epac is involved in long term potentiation at cerebellar granule cell-to-Purkinje cell synapses. Thus, the pharmacological activation of $\beta$ ARs modulates synaptic plasticity and opens therapeutic opportunities to control this phenomenon.

Received Mar. 27, 2020; revised Sep. 25, 2020; accepted Oct. 1, 2020.

Author contributions: R.M., D.B.-M., J.J.F., M.T., and J.S.-P. designed research; R.M., N.G.-F., A.S.S.-P., and R.L. performed research; R.M., N.G.-F., A.S.S.-P., and R.L. analyzed data; J.S.-P. wrote the paper.

This work was supported by the Ministerio de Economía, Industria y Competitividad (Grant BFU 2013-43163R to J.S.-P.; Grant BFU 2012-32105 to M.T.) and the Ministerio de Ciencia e Innovación (Grant BFU2017-83292-R), the "Instituto de Salud Carlos III" (Grants RD12/0014 and RD16/0019), and the Community of Madrid (Grant B2017/BMB-3699) to J.S.-P. and M.T. This work was also supported by Grant SBPLY/17/180501/000229 from the Junta de Comunidades de Castilla-La Mancha to R.L. We thank Prof. Susumu Seino (Kobe University, Kobe, Japan) for providing the Epac2 KO mice. We also thank María Luisa García and Miriam González at the electron microscopy facility of the Universidad Complutense de Madrid for technical support; María del Carmen Zamora for excellent technical assistance; and Dr. Mark Sefton for editorial assistance.

The authors declare no competing financial interests.

Correspondence should be addressed to Ricardo Martín at rmartinh@ucm.es or José Sánchez-Prieto at jsprieto@ucm.es.

https://doi.org/10.1523/JNEUROSCI.0716-20.2020

Copyright $\odot 2020$ the authors 


\section{Introduction}

The second messenger cAMP is an important determinant of presynaptic function, with increases in cAMP potentiating glutamate release (Herrero and Sánchez-Prieto, 1996; Millán et al., 2002) and synaptic transmission (Chavez-Noriega and Stevens, 1994; Chen and Regehr, 1997; Sakaba and Neher, 2001; Kaneko and Takahashi, 2004). Presynaptic forms of synaptic plasticity are also driven by cAMP, which involves enhanced neurotransmitter release (Salin et al., 1996; Villacres et al., 1998; Castillo et al., 2002). The mechanism by which cAMP potentiates neurotransmitter release does not affect $\mathrm{Ca}^{2+}$ influx or the action potential waveforms (Chen and Regehr, 1997; Kaneko and Takahashi, 2004), yet it does modify the release machinery. The readily releasable pool (RRP) of synaptic vesicles (SVs) is made up of docked and primed vesicles, with these latter vesicles in a state where $\mathrm{Ca}^{2+}$ influx triggers their fusion. The availability of cAMP heightens the size and release probability $\left(\mathrm{P}_{\mathrm{r}}\right)$ of the RRP (Chen and Regehr, 1997; Sakaba and Neher, 2001; Kaneko and Takahashi, 2004; Yao and Sakaba, 2010), although the source of this cAMP remains to be established. Significantly, $\beta$-adrenergic receptors ( $\beta$ ARs) are expressed in axons that establish asymmetric glutamatergic synapses (Ferrero et al., 2013), and they can activate adenylyl cyclase and generate cAMP, which through its downstream signaling may in turn potentiate glutamate release (Herrero and Sánchez-Prieto, 1996; Millán et al., 2002; Ferrero et al., 2016), synaptic transmission, and plasticity (Huang et al., 1996; Huang and Hsu, 2006).

Long-term potentiation (LTP) at parallel fiber (PF)-Purkinje cell (PC) synapses depends on a $\mathrm{Ca}^{2+}$-induced increase in presynaptic cAMP (Salin et al., 1996), as mediated by $\mathrm{Ca}^{2+}$-sensitive adenylyl cyclases (Storm et al., 1998). However, the upstream and downstream signaling elements involved in this presynaptic form of plasticity are poorly understood. Indeed, while $\beta$ ARs participate in presynaptic and cAMP-dependent LTP in the cerebral cortex (Huang and Hsu, 2006), and noradrenergic varicosities are seen in apposition at PF-PC contacts (Abbott and Sotelo, 2000), it remains unclear whether these receptors are required for PF-PC LTP. The active zone (AZ) Rab-3-interacting protein (RIM1 $\alpha$ ) might represent a downstream target of cAMPdependent protein kinase A (PKA) in PF-PC LTP (Linden and Ahn, 1999; Castillo et al., 2002; Lonart et al., 2003), although this is yet to be confirmed (Kaeser et al., 2008; Kintscher et al., 2013). By contrast, the guanine nucleotide exchange proteins directly activated by cAMP (Epac) proteins (Epac1-2) are alternative cAMP targets to PKA. Indeed, Epac 2 is abundant in the cerebellum (Kawasaki et al., 1998), and its deletion impairs presynaptic hippocampal mossy fiber cAMP-dependent LTP (Fernandes et al., 2015).

We found that $\beta \mathrm{AR}$ activation enhanced the amplitude of EPSCs at PF-PC synapses by a presynaptic mechanism that diminished the paired-pulse ratio (PPR), while increasing the frequency of asynchronous quantal events. These effects were consistent with the immunoelectron microscopy identification of $\beta 1 \mathrm{ARs}$ at PF boutons. $\beta$ AR synaptic potentiation was insensitive to PKA inhibitors (H-89, KT270), yet it was blocked by the Epac inhibitor ESI 05 and was mimicked by the Epac activator 8pCPT. Moreover, this potentiation was associated with an increase in SV docking. Interestingly, presynaptic PF-PC LTP was associated with an increase in the size of the RRP of SVs, while it was absent in the presence of the $\beta$ AR1 antagonist metoprolol and in cerebellar slices from Epac2-null mice. Thus, $\beta$ ARs appear to activate a physiologically relevant signaling pathway that involves cAMP- and Epac2-dependent modulation of the SV release machinery required for presynaptic PF LTP.

\section{Materials and Methods}

Electrophysiology. All procedures for the handling of animals were performed in accordance with European Commission guidelines (2010/ 63/EU), and they were approved by the Animal Research Committee at the Complutense University. Wild-type (WT) and Epac2 knock-out (KO) mice (22-30 d of age), of either sex, were anesthetized with isoflurane $(1.5-2 \%$ in a mixture of $80 \%$ synthetic air $20 \%$ oxygen), and they were then killed by decapitation. Parasagittal vibratome slices of the cerebellum ( $325 \mu \mathrm{m}$ thick; model VT 1200S, Leica) were maintained in icecold Ringer's solution, and recordings at PF-PC synapses were obtained as described previously (Salin et al., 1996; Castillo et al., 2002). The slices were kept in a holding chamber containing Ringer's solution for at least $1 \mathrm{~h}$ and then transferred to a superfusion chamber to record in superfusion medium equilibrated with $95 \% \mathrm{O}_{2} / 5 \% \mathrm{CO}_{2}$ and containing the following: $119 \mathrm{~mm} \mathrm{NaCl}, 2.5 \mathrm{~mm} \mathrm{KCl}, 1.3 \mathrm{~mm} \mathrm{MgSO}_{4}, 2.5 \mathrm{~mm} \mathrm{CaCl}_{2}, 26$ $\mathrm{mm} \mathrm{NaHCO}, 1 \mathrm{~mm} \mathrm{NaH} \mathrm{PO}_{4}, 10 \mathrm{~mm}$ glucose, and $100 \mu \mathrm{M}$ picrotoxin (to block $\mathrm{GABA}_{\mathrm{A}}$ receptors). In some experiments, $0.5 \mathrm{~mm}$ ascorbic acid was added to the superfusion medium to avoid the oxidation of norepinephrine. The flow rate was established at $1 \mathrm{ml} / \mathrm{min}$ and recordings were obtained at $25^{\circ} \mathrm{C}$ maintained using a temperature controller (model TC324C, Warner Instruments).

Theta capillaries $(2-5 \mu \mathrm{m}$ tip) filled with Ringer's solution were used for bipolar stimulation. The electrodes were connected to a stimulator (model S38, GRASS) through an isolation unit and placed near the pial surface of the molecular layer to stimulate the PF input to PCs. Stimuli $(<50 \mu \mathrm{A}, 100 \mu \mathrm{s})$ were delivered at $0.05 \mathrm{~Hz}$, with paired pulses administered $80 \mathrm{~ms}$ apart to obtain the PPR as EPSC2/EPSC1.

Whole-cell recordings from individual PCs were obtained with a PCONE amplifier (Dagan Corporation) under voltage-clamp conditions, and the membrane potential was held at $-70 \mathrm{mV}$ to record glutamatergic-evoked EPSCs. Signals were fed to a Pentium-based PC through a DigiData1322A interface board (Axon Instruments), and the pCLAMP version 10.2 software (Molecular Devices) was used to generate the stimuli, as well as for data display, acquisition, storage, and analysis. Patch pipettes were pulled from thin-walled borosilicate glass capillary tubes (outer diameter, $1.5 \mathrm{~mm}$ ) on a P-97 puller (Sutter Instrument), and the pipettes (3-4 M $\Omega$ ) were filled with an internal solution containing the following: $122.5 \mathrm{~mm}$ cesium gluconate, $10 \mathrm{~mm}$ HEPES, $10 \mathrm{~mm}$ BAPTA, 2 mм Mg-ATP, $8 \mathrm{~mm} \mathrm{NaCl}$, and $5 \mathrm{~mm}$ QX-314- $\mathrm{Br}$, pH 7.3, adjusted with $\mathrm{CsOH}$ to an osmolarity of $290 \mathrm{mOsm}$. Series and input resistances were monitored throughout the experiment using a $-5 \mathrm{mV}$ pulse, and the recordings were considered stable when the series and input resistances, resting membrane potential, and stimulus artifact duration did not change $>20 \%$. Cells that did not meet these criteria were discarded in all of the experiments. To avoid irreversible effects of agonists/antagonist/ inhibitors or LTP protocols, only one neuron per slice was analyzed.

The presence of the $\mathrm{Ca}^{2+}$ chelator BAPTA in the recording pipette (Safo and Regehr, 2005) may prevent the generation of endocannabinoids by PCs (Kreitzer and Regehr, 2001; Maejima et al., 2001) and the postsynaptic PC LTP mediated by cAMP, also impeding the Epac-dependent increase in GluA3-containing AMPA receptor (AMPAR) permeability (Gutierrez-Castellanos et al., 2017).

To measure PF asynchronous EPSCs (aEPSCs), $\mathrm{CaCl}_{2}$ was replaced with $2.5 \mathrm{~mm} \mathrm{SrCl}_{2}$, the stimuli were adjusted to yield a EPSC amplitude between 150 and $250 \mathrm{pA}$, and they were delivered every $20 \mathrm{~s}$. Asynchronous release associated with each stimulus was estimated after $20 \mathrm{~ms}$ and over $500 \mathrm{~ms}$. The asynchronous events associated with the last six stimuli of a $5 \mathrm{~min}$ period were quantified in the basal condition and after $10 \mathrm{~min}$ in the presence of isoproterenol $(100 \mu \mathrm{M})$.

To induce LTP, a tetanic train of 100 stimuli was delivered at $10 \mathrm{~Hz}$ at least $15 \mathrm{~min}$ after the beginning of the recording to allow sufficient time for the diffusion of BAPTA into the dendritic tree. The baseline PFevoked EPSC amplitude was maintained at $<300 \mathrm{pA}$ to avoid sodium spikes that escaped the voltage clamp, particularly during and after tetanization. The size of the RRP was estimated as described previously (Schneggenburger et al., 1999; Gioia et al., 2016). To minimize the variation in these estimates, the stimulus intensity before LTP induction was adjusted to yield EPSC amplitudes between 150 and $200 \mathrm{pA}$. Thus, $30 \mathrm{~min}$ after applying the $10 \mathrm{~Hz}$ train to induce presynaptic LTP, a 
further tetanic train was applied (100 stimuli at $40 \mathrm{~Hz}$ ). The cumulative EPSC amplitudes during this train were plotted, and the $y$-intercept extended from the linear part of the curve (over times $>1.5 \mathrm{~s}$ when the cumulative amplitude curve reached steady state), and it was used to estimate the RRP size. Moreover, the slope of this fitted line was used to estimate the RRP replenishment rate (all of these data were plotted and fitted using OriginLab 8 software). Finally, the mean probability of vesicle release $\left(p_{\text {ves }}\right)$ was obtained by dividing the average of six consecutive EPSCs before the $40 \mathrm{~Hz}$ train by the estimated RRP size in each cell.

Immunoelectron microscopy. Immunohistochemistry for electron microscopy (EM) was conducted using the pre-embedding Immunogold method, as described previously (Luján et al., 1996). Three adult C57BL/6 mice [postnatal day 60 (P60)] were anaesthetized and perfused transcardially with ice-cold fixative containing $4 \%$ paraformaldehyde, $0.05 \%$ glutaraldehyde, and $15 \%(\mathrm{v} / \mathrm{v})$ saturated picric acid diluted to $0.1 \mathrm{~m}$ phosphate buffer (PB), pH 7.4. After perfusion, the brain of the animal was removed, washed thoroughly in $0.1 \mathrm{M} \mathrm{PB}$, and $60-\mu \mathrm{m}$-thick coronal vibratome sections were obtained (model V1000, Leica). The free-floating sections were incubated in $10 \%(\mathrm{v} / \mathrm{v})$ normal goat serum (NGS) diluted in Tris-buffered saline (TBS) and then with goat $\beta 1 \mathrm{AR}$ antibodies (Sigma-Aldrich) at a final protein concentration of $3-5 \mu \mathrm{g} / \mathrm{ml}$ in TBS containing $1 \%$ (v/v) NGS. After several washes in TBS, the sections were incubated with $1.4 \mathrm{~nm}$ gold coupled rabbit antigoat IgG (Nanoprobes). The sections were postfixed in $1 \%(\mathrm{v} / \mathrm{v})$ glutaraldehyde and washed in double-distilled water before performing silver enhancement of the gold particles with an HQ Silver Kit (Nanoprobes). The sections were then treated with osmium tetroxide ( $1 \%$ in $0.1 \mathrm{M} \mathrm{PB})$, block-stained with uranyl acetate, dehydrated in a graded series of ethanol and flat-embedded on glass slides in Durcupan (Fluka) resin. Regions of interest were cut at a thickness of 70-90 nm on an ultramicrotome (Reichert Ultracut E, Leica) and collected on single-slot Pioloform-coated copper grids. Staining was performed using drops of $1 \%$ aqueous uranyl acetate followed by Reynolds's lead citrate stain, and the ultrastructure of the tissue was analyzed on a JEM 1010 electron microscope (JEOL).

Quantification of adrenergic receptors. To establish the relative abundance of the $\beta 1 \mathrm{AR}$ subunits in the molecular layer of the cerebellum, we quantified their immunolabeling in $60 \mu \mathrm{m}$ coronal sections processed for pre-embedding Immunogold immunohistochemistry following a procedure similar to that used previously (Luján et al., 1996). Briefly, three tissue samples were obtained from three different animals and embedded in blocks. To minimize false negatives, ultrathin sections were cut close to the surface of each block. We estimated the quality of immunolabeling by selecting areas with optimal gold labeling at approximately the same distance from the cut surface. Randomly selected areas were then photographed from the selected ultrathin sections at a final magnification of $45,000 \times$, and the Immunogold labeling was quantified in sampling areas of each cortex totaling $\sim 1500 \mu \mathrm{m}^{2}$. Immunoparticles for individual $\beta 1 \mathrm{AR}$ subunits at the plasma membrane of axon terminals were counted in each sampling area, analyzing the neuropile of the molecular layer containing postsynaptic and presynaptic compartments. In terms of the presynaptic compartments, only axon terminals (PF terminals) establishing synaptic contacts with dendritic spines of PCs were analyzed. A total of 285 gold particles were counted at the axon terminals immunostained for $\beta$ 1ARs. Subsequently, the proportion of immunoparticles for the $\beta 1 \mathrm{AR}$ subunits at the $\mathrm{AZ}$ and in the extrasynaptic plasma membrane of axon terminals was calculated, as well as the proportion of postsynaptic versus presynaptic elements stained for $\beta 1 \mathrm{AR}$.

Controls. To determine the specificity of the methods used in the immunoelectron microscopy studies, the primary antibody was either omitted or replaced with $5 \%(\mathrm{v} / \mathrm{v})$ of normal serum from the species of the primary antibody. No specific labeling was observed in these conditions. Labeling was also compared with that obtained for calretinin and calbindin, and only antibodies against $\beta 1 \mathrm{AR}$ consistently labeled the plasma membrane.

Synaptic vesicle distribution by electron microscopy. Parasagittal slices $(325 \mu \mathrm{m}$ thick) from the cerebellum were obtained as described above for the electrophysiology experiments and transferred to an immersion recording chamber. The slices were superfused at $1 \mathrm{ml} / \mathrm{min}$ with gassed Ringer's solution containing picrotoxin $(100 \mu \mathrm{M})$, and, in some cases, the slices were also treated for $10 \mathrm{~min}$ with isoproterenol $(100 \mu \mathrm{M})$. The slices from WT and Epac2 KO mice were fixed immediately afterward by immersion for $45 \mathrm{~min}$ at $37^{\circ} \mathrm{C}$ in $3.5 \%$ glutaraldehyde in $0.1 \mathrm{M} \mathrm{PB}, \mathrm{pH} 7.4$, and they were then left in glutaraldehyde solution for $30 \mathrm{~min}$ at room temperature before storing them for $20 \mathrm{~h}$ at $4^{\circ} \mathrm{C}$. The slices were then rinsed six times with large volumes of $0.1 \mathrm{M} \mathrm{PB}$, and the cerebellum was dissected out and postfixed for $1 \mathrm{~h}$ at room temperature 


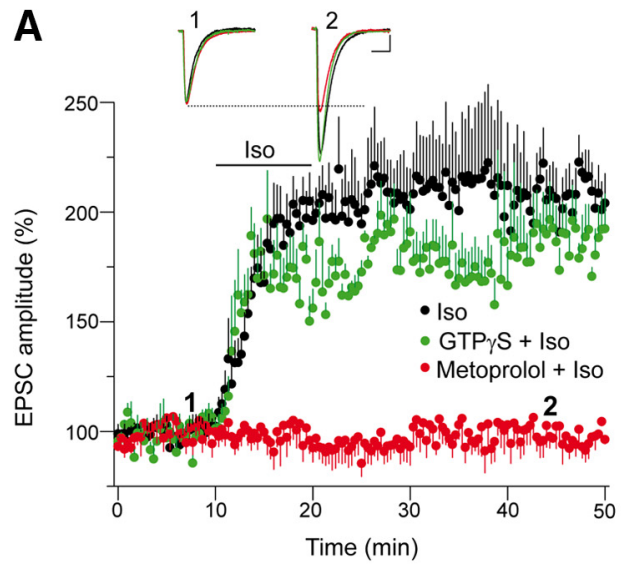

B
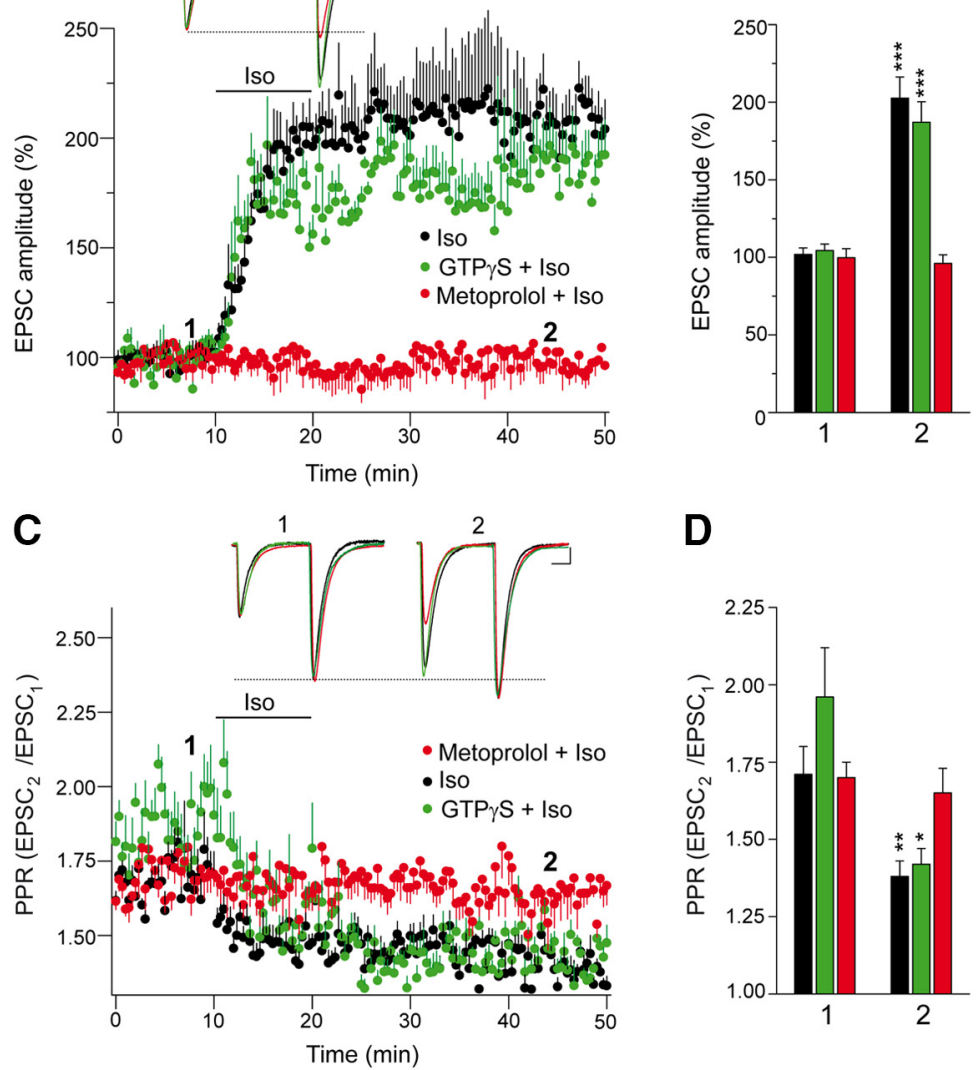

D

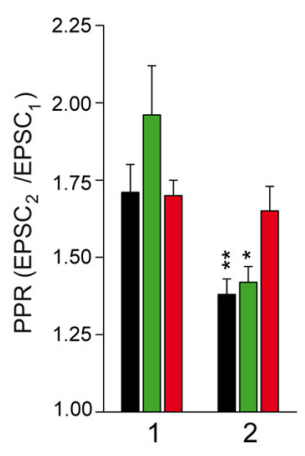

Figure 2. Isoproterenol potentiates synaptic transmission at PF-PC synapses by a presynaptic mechanism involving $\beta$ 1-adrenergic receptors. EPSCS were recorded from Purkinje cells after $0.05 \mathrm{~Hz}$ parallel fiber stimulation. $\boldsymbol{A}$, The $\beta$ AR agonist isoproterenol (100 $\mu \mathrm{m}, 10 \mathrm{~min})$ induced a sustained increase in the EPSC amplitude that was sensitive to the specific $\beta$ 1AR antagonist metoprolol (60 $\mu \mathrm{m}, 30 \mathrm{~min}$ ), yet was insensitive to the presence of GTP $\gamma \mathrm{S}(1 \mathrm{~mm}, 15 \mathrm{~min})$ in the recording pipette. $\boldsymbol{B}$, Quantification of the changes in EPSC amplitude induced by isoproterenol. The data were measured 40 min after isoproterenol application (2) in the absence $(n=13$ cells $/ 13$ slices, 6 mice, $t=7.075, \mathrm{df}=14$ ) or the presence ( $n=11$ cells $/ 11$ slices $/ 5$ mice, $t=0.4426, \mathrm{df}=20)$ of metoprolol or GTP- $\gamma-S(n=11$ cells $/ 11$ slices $/ 5$ mice, $t=5.983$, $\mathrm{df}=11$ ), and relative to the values before isoproterenol application (1). C, Changes in the PPR (EPSC2/EPSC1) induced by isoproterenol in the different conditions. $D$, Quantification of the changes in the PPR induced by isoproterenol (2) in the absence $(t=3.205, \mathrm{df}=18)$ and presence $(t=0.53, \mathrm{df}=20)$ of $\mathrm{GTP} \gamma \mathrm{S}(t=3.221, \mathrm{df}=11)$ or metoprolol, and relative to the respective basal values (1). EPSC sample traces $(\boldsymbol{A}, \boldsymbol{C})$ represent the mean of six consecutive EPSCS at $0.05 \mathrm{~Hz}$ taken before and $40 \mathrm{~min}$ after treatment. Calibration: $50 \mathrm{pA}$ and $15 \mathrm{~ms}$. The data represent the mean \pm SEM.

in $1 \% \mathrm{OsO}_{4}-1.5 \% \mathrm{~K}_{3} \mathrm{Fe}(\mathrm{CN})_{6}$. After dehydrating through a graded series of ethanol $(30,50,70,80,90,95$, and $100 \%)$, the samples were embedded using the SPURR embedding kit (TAAB). Ultrathin ultramicrotome sections (70-80 $\mathrm{nm}$ thick; model EM UC6 Ultramicrotome, Leica Microsystems) were routinely stained with uranyl acetate and lead citrate, and images were obtained on a JEM 1010 transmission electron microscope (JEOL). Randomly chosen areas of the cerebellar molecular layer were photographed at 80,000 $\times$ magnification, and only asymmetric synapses with clearly identifiable electron-dense postsynaptic densities were analyzed with ImageJ software. The total number of SVs per synaptic terminal was determined, and the distance between the outer layer of the vesicle and the inner layer of the $\mathrm{AZ}$ was measured. These data were distributed in $10 \mathrm{~nm}$ bins, and the SVs up to a maximum of $10 \mathrm{~nm}$ from the AZ were considered as docked vesicles. The SV data were also were distributed in $5 \mathrm{~nm}$ bins to distinguish fully primed and tightly docked SVs $(0-5 \mathrm{~nm})$ from loosely docked SVs $(5-10 \mathrm{~nm})$. All the data were analyzed blind to the genotype and treatment.

Experimental design and statistical analysis. The data were analyzed using Instat or OriginPro 8.0 software, applying an unpaired two-tailed Student's $t$ test. When the variances of the populations were differed significantly, a Welch's test was applied, and, when more than two groups were compared, an ANOVA with a Bonferroni's post hoc test was used.
The data are represented as the mean \pm SEM: ${ }^{*} p<0.05,{ }^{* *} p<0.01,{ }^{* *} p<0.001$. Differences were considered statistically significant at $p<$ 0.05 with a confidence limit of $95 \%$.

\section{Results}

Norepinephrine and isoproterenol potentiate synaptic transmission at PF-PC synapses through a presynaptic mechanism involving $\beta 1$ ARs

Noradrenergic innervation of the cerebellum is important to modulate its activity, and, as such, noradrenergic fibers are distributed diffusely throughout the cerebellar cortex. Indeed, noradrenergic varicosities are opposed to dendritic profiles that largely belong to PCs (Abbott and Sotelo, 2000). When we tested whether noradrenaline modulates synaptic transmission at $\mathrm{PF}-\mathrm{PC}$ synapses, we found it increased the EPSC amplitude at these synapses from a basal state of $100.9 \pm 3.4 \%$ to $194.1 \pm$ $11.2 \%(n=10 ; p<0.0001$, Welch's test; Fig. $1 A, B)$. This potentiation was prevented by the specific $\beta 1 \mathrm{AR}$ antagonist metoprolol (from $97.9 \pm 7.7$ to $101.9 \pm 4.1 \%$; $n=4$; $p=0.6627$, Student's $t$ test; Fig. $1 A, B)$. The potentiation of EPSC amplitudes by norepinephrine is associated with a decrease in the EPSC2/EPSC1 PPR from a value of 1.72 \pm 0.05 under basal conditions to $1.41 \pm$ 0.02 on exposure to norepinephrine $(p=$ 0.0001 , Welch's test; Fig. $1 C, D$ ). Hence, the noradrenaline-induced increase in EPSC amplitude is the result of presynaptic $\beta 1 \mathrm{AR}$ activation, which enhances glutamate release.

The $\beta$ AR agonist isoproterenol also increases the amplitude of EPSCs at PF-PC synapses (from a basal state of $101.9 \pm$ $4.2 \%$ to $202.6 \pm 13.6 \% ; n=13 ; p<0.0001$, Welch's test; Fig. $2 A, B$ ), and this potentiation was prevented by the specific $\beta 1 \mathrm{AR}$ antagonist metoprolol (from $99.7 \pm 5.9 \%$ to $96.1 \pm 5.6 \% ; n=11 ; p=0.6628$, Student's $t$ test; Fig. $2 A, B)$. To exclude the activation of postsynaptic $\beta$ ARs (Lippiello et al., 2015), we substituted GTP for the nonhydrolyzable GTP $\gamma S$ in the recording pipette, although this did not prevent isoproterenol from increasing the EPSC amplitudes (from $104.4 \pm 4.1 \%$ to $187.1 \pm$ $13.2 \% ; n=11 ; p<0.0001$, Welch's test; Fig. $2 A, B)$. Thus, the enhancement to EPSC amplitudes provoked by isoproterenol is not mediated by the activation of postsynaptic $\beta$ ARs at PF-PC synapses. This potentiation of the EPSC amplitudes by isoproterenol is associated with a decrease in the EPSC2/EPSC1 PPR from a basal value of $1.71 \pm 0.09$ to $1.38 \pm 0.05 ; p=0.0049$, Welch's test; Fig. $2 C, D)$. Hence, the isoproterenol-induced increase of EPSC amplitude is the result of presynaptic $\beta 1 \mathrm{AR}$ activation enhancing glutamate release.

\section{Subcellular localization of $\beta 1$ ARs in the presynaptic compartments of the cerebellum}

The distribution of $\beta 1 \mathrm{ARs}$ in the presynaptic compartment of $\mathrm{PF}-\mathrm{PC}$ synapses was assessed in the cerebellar molecular layer by 

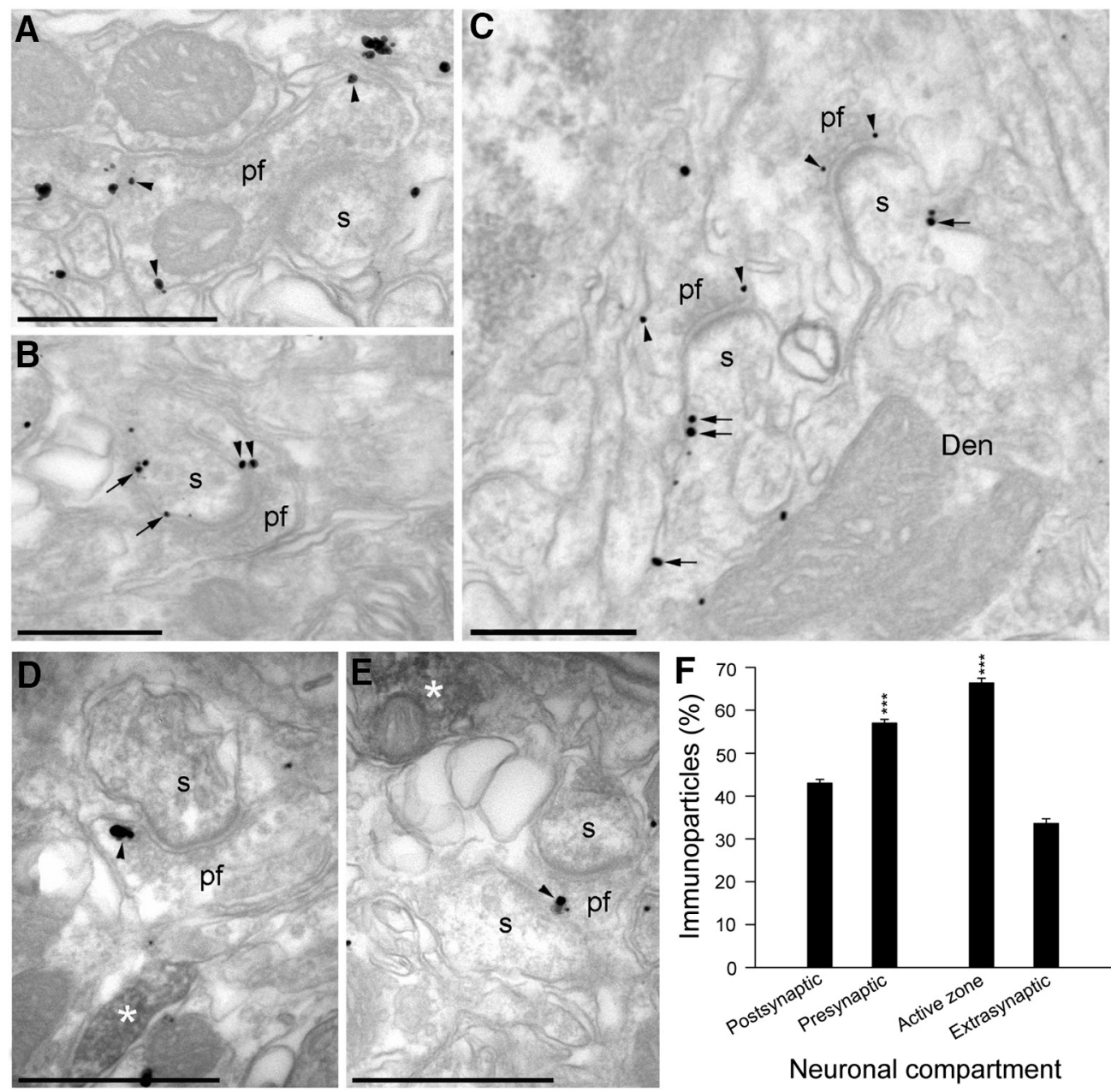

Figure 3. Subcellular localization of the $\beta 1$-adrenergic receptors in the presynaptic compartments of the cerebellum. $\boldsymbol{A}-\boldsymbol{C}$, Electron micrographs of the molecular layer of the cerebellum showing pre-embedding Immunogold staining for $\beta$ 1AR. Immunoparticles for $\beta$ 1AR were observed along the plasma membrane (arrowheads) of parallel fiber terminals (pf) establishing excitatory synapses with dendritic spines (s) of PCs. Less frequently, immunoparticles for $\beta 1 \mathrm{AR}$ were also observed at postsynaptic sites along the plasma membrane (arrows) of dendritic spines (s) and the shafts (Den) of PCS. D, E, Electron micrographs of the molecular layer of the cerebellum showing $\beta$ 1AR immunoparticles and the immunoperoxidase reaction for TH detected using a dual-labeling pre-embedding method. $\beta$ 1AR immunoparticles were observed along the plasma membrane (arrowheads) of pf terminals, always close to fibers immunopositive for TH (filled with the peroxidase reaction end product, white asterisks). $\boldsymbol{F}$, Quantitative analysis showing the percentage of $\beta$ 1AR immunoparticles in the molecular layer of the cerebellum. Immunoparticles (502) for $\beta 1$ ARs were more frequently observed in presynaptic compartments $(57.0 \pm 0.9 \%)$ and within axon terminals than in the postsynaptic compartments $(43.0 \pm 0.9 \%, t=10.999, \mathrm{df}=4)$. Moreover, they were more frequently found in the active zone $(66.4 \pm 1.1 \%, t=21.085, \mathrm{df}=4)$ than at extrasynaptic sites $(33.6 \pm 1.1 \%)$. Scale bars: $\boldsymbol{A}$, $D, E, 500 \mathrm{~nm} ; \boldsymbol{B}, \boldsymbol{C}, 200 \mathrm{~nm}$. The data represent the mean \pm SEM.

examining the immunoparticles detected in electron micrographs. $\beta 1 \mathrm{AR}$ immunoparticles were observed along the plasma membrane (arrowheads) of PF terminals (Fig. $3 A-C$, pf), establishing excitatory synapses with dendritic spines (Fig. $3 A-C$, s) on PCs. Less often, immunoparticles for $\beta 1 \mathrm{AR}$ were also observed at postsynaptic sites along the plasma membrane (arrows) of PC dendritic spines (Fig. $3 A-C$, s) and shafts (Fig. $3 A-C$, Den). The distribution of $\beta$ 1ARs was also studied in electron micrographs of the molecular layer of the cerebellum stained for tyrosine hydroxylase (TH) using an immunoperoxidase reaction. $\beta$ 1ARs were observed along the plasma membrane (Fig. 3D,E, arrowheads) of PF terminals (Fig. 3D,E, pf), always close to fibers immunostained for $\mathrm{TH}$ (Fig. 3D,E, white asterisks). Quantification of the $\beta 1 \mathrm{AR}$ immunoparticles ( $n=502$ from three preparations) in the molecular layer of the cerebellum indicates that they were more frequent in presynaptic compartments $(57.0 \pm 0.9 \% ; p=0.0004$, Student's $t$ test), and that they were more frequent at the $\mathrm{AZ}$ of axon terminals (66.4 \pm $1.1 \% ; p<0.0001$, Student's $t$ test) than at extrasynaptic sites (33.6 \pm $1.1 \%$; Fig. $3 F$ ). Thus, $\beta$ 1ARs are clearly present in PF-PC synapses.
Isoproterenol potentiation of synaptic transmission at PF-PC synapses involves Epac rather than PKA-dependent signaling

The downstream elements involved in the cAMP signaling associated with $\beta$ AR-induced potentiation remain controversial, involving either PKA-dependent mechanisms (Herrero and Sánchez-Prieto, 1996; Huang and Hsu, 2006) or PKA-independent mechanisms (Huang and Hsu, 2006; Gekel and Neher, 2008; Ferrero et al., 2013; Fernandes et al., 2015). In a set of experiments independent from those presented above (Fig. $2 A, B$ ), we showed that the isoproterenol-induced increase in EPSC amplitude at PF-PC synapses (from $100.8 \pm 4.1 \%$ to $201.8 \pm 15.4 \%$; $n=11 ; p<0.0001$, Welch's test) was not altered by the PKA inhibitors H-89 (from $99.8 \pm 4.4 \%$ to $206.5 \pm 11.4 \%$; $n=11$; $p=0.0004$, Welch's test) or KT5720 (from $98.9 \pm 4.5 \%$ to $200.0 \pm 7.7 \% ; n=11 ; p<0.0001$, Welch's test; Fig. $4 A, B)$. Some presynaptic effects of $\beta$ ARs are mediated by cAMP acting through Epac proteins (Kaneko and Takahashi, 2004; Huang and Hsu, 2006; Gekel and Neher, 2008; Yang et al., 2012; Ferrero 


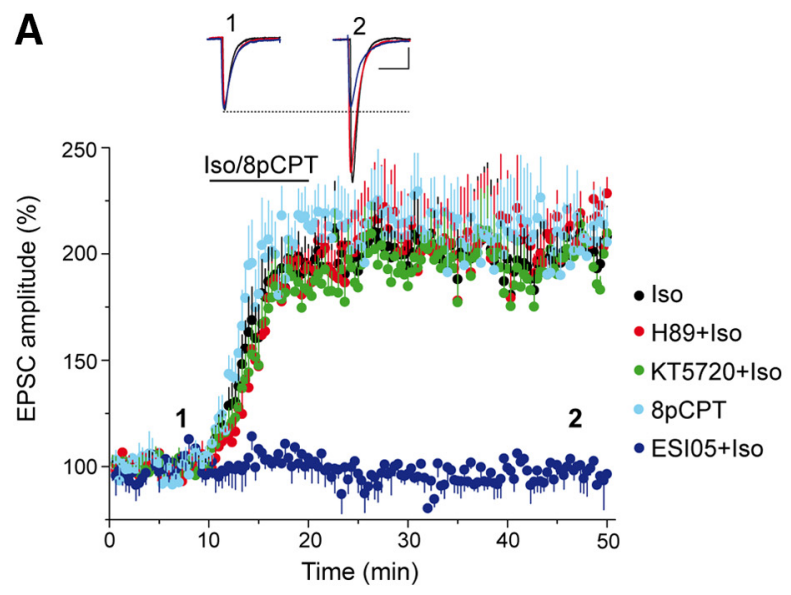

B
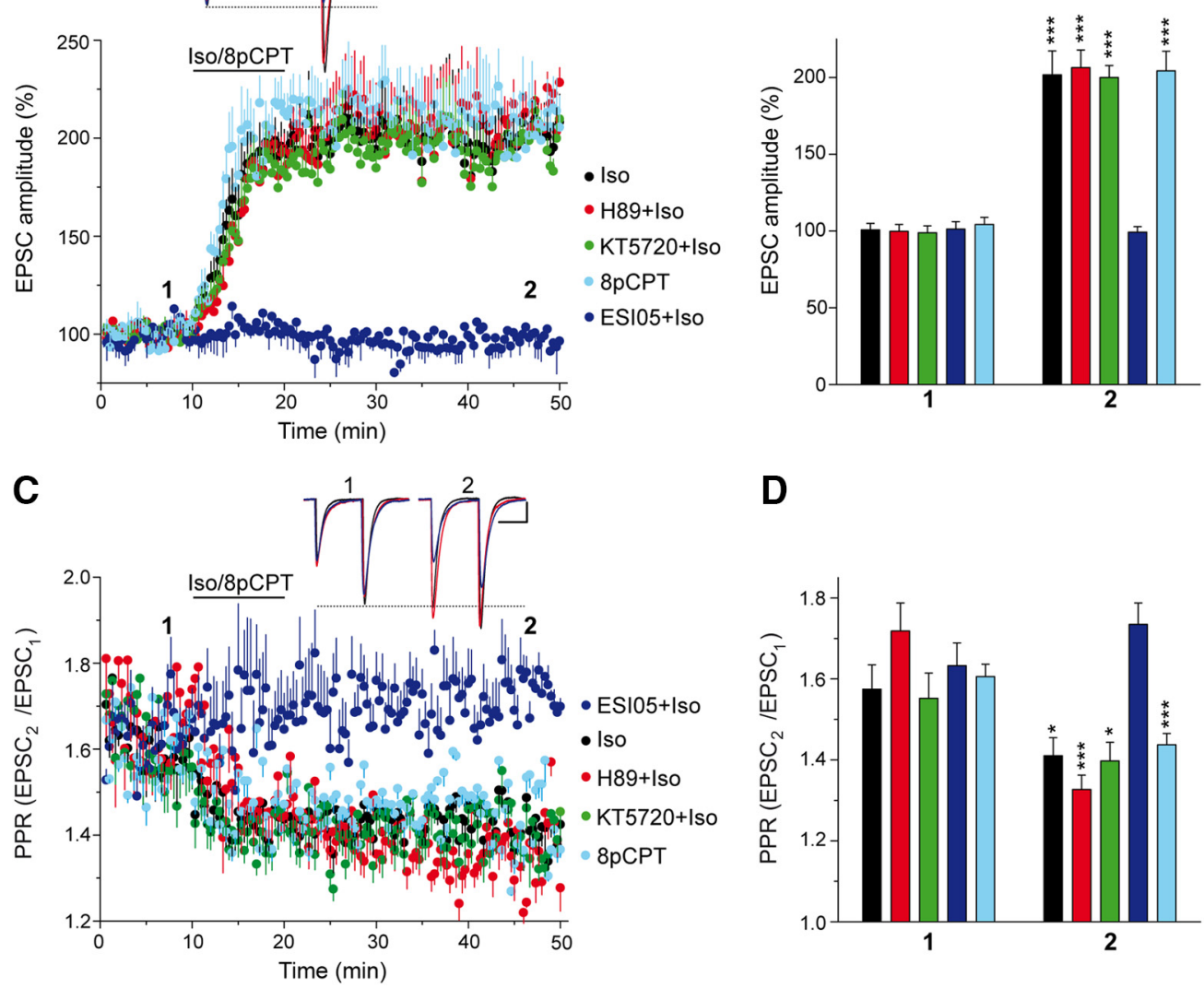

D

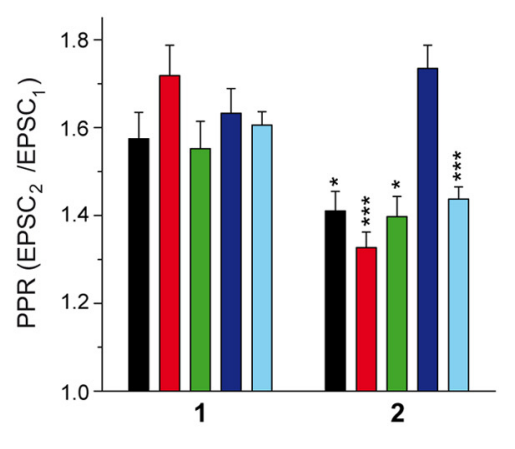

Figure 4. Isoproterenol potentiation of synaptic transmission at PF-PC synapses involves Epac but not PKA-dependent signaling. $\boldsymbol{A}$, The $\beta$ AR agonist isoproterenol (100 $\mu \mathrm{m}, 10 \mathrm{~min})$ induced a sustained increase in the EPSC amplitude that was insensitive to the PKA inhibitors H-89 (10 $\mu \mathrm{m}, 30 \mathrm{~min})$ and KT-5720 ( $2 \mu \mathrm{m}, 30$ min). However, this response was absent in the presence of the Epac2 inhibitor ESI $05(10 \mu \mathrm{m}, 30 \mathrm{~min})$, and it was mimicked by the Epac activator 8pCPT (50 $\mu \mathrm{m}, 10 \mathrm{~min})$. B, Quantification of the changes in EPSC amplitude measured $40 \mathrm{~min}$ after isoproterenol/8p(PT application (2). Isoproterenol in the absence $(n=11$ cells $/ 11$ slices, 5 mice, $t=6.344, \mathrm{df}=11)$ or in the presence of $\mathrm{H}-89(n=11$ cells $/ 11$ slices $/ 5$ mice, $t=4.496, \mathrm{df}=11), \mathrm{KT}-5720$ ( $n=11$ cells/11slices/5 mice, $t=5.945, \mathrm{df}=11)$, or ESI $05(n=10$ cells $/ 10$ slices $/ 4$ mice, $t=0.3760, \mathrm{df}=11)$, or $8 \mathrm{p}$ CPT alone $(n=12$ cells $/ 12$ slices $/ 5 \mathrm{mice}$, $t=4.850 \mathrm{df}=13)$. All the data were compared with the respective values before isoproterenol or $8 \mathrm{pCPT}$ application (1). C, Changes in the PPR (EPSC2/EPSC1) induced by isoproterenol or $8 \mathrm{pCPT}$ in the different conditions. D, Quantification of the changes in the PPR induced by $8 \mathrm{pCPT}(t=4.230, \mathrm{df}=21)$ and isoproterenol $(2)$ in the absence $(t=2.219, \mathrm{df}=20)$ or presence of $\mathrm{H}-89(t=4.941, \mathrm{df}=18), \mathrm{KT}-5720(t=2.133, \mathrm{df}=8)$ or ESI $05(t=1.28, \mathrm{df}=18)$, and relative to the respective basal values $(1)$. EPSC sample traces $(\boldsymbol{A}, \boldsymbol{C})$ represent the mean of six consecutive EPSCs at $0.05 \mathrm{~Hz}$ taken before and $40 \mathrm{~min}$ after treatment. Calibration: $50 \mathrm{pA}$ and $15 \mathrm{~ms}$. The data represent the mean \pm SEM.

et al., 2013; Ramírez-Franco et al., 2014; Fernandes et al., 2015; Alonso et al., 2017). Indeed, when we assessed the effect of the selective Epac2 inhibitor ESI 05 that binds to the interface formed between the two unique cAMP binding domains of Epac2 (Tsalkova et al., 2012), there was a clear impairment of the isoproterenol-induced increase in EPSC amplitude (from $101.3 \pm 4.8 \%$ to $99.3 \pm 3.5 \% ; n=10 ; p=0.7125$, Welch's test; Fig. $4 A, B)$. Conversely, the Epac activator $8 \mathrm{pCPT}$ potentiated synaptic transmission (from $104.3 \pm 4.6 \%$ to $204.3 \pm 12.7 \% ; n=12$; $p=0.0003$, Welch's test; Fig. $4 A, B$ ), which also involved a presynaptic mode of action as this potentiation was associated with a decrease in the EPSC2/EPSC1 PPR (basal: $1.61 \pm 0.03$ and $1.43 \pm 0.03$ after 8 pCPT; $n=12 ; p=0.0004$, Student's $t$ test; Fig. $4 C, D)$. Thus, Epac proteins are downstream targets of cAMP in the potentiation of PF-PC synaptic transmission by $\beta$ ARs.

Isoproterenol and $8 \mathrm{pCPT}$ enhance the frequency but not the amplitude of asynchronous release events

The presynaptic origin of the isoproterenol-induced potentiation can be assessed by measuring the changes in the frequency but not the amplitude of miniature EPSCs (mEPSCs). However, as it is not possible to distinguish between PF-mEPSCs from climbing fiber mEPSCs (Carey and Regehr, 2009), we measured the amplitude and frequency of PF-mEPSCs in the presence of $\mathrm{Sr}^{2+}$, which induces an asynchronous release of vesicles (i.e., aEPSCs; Goda and Stevens, 1994; Xu-Friedman and Regehr, 1999; Carey and Regehr, 2009). Under these conditions, aEPSCs can be attributed to $\mathrm{PF}$ stimulation and in the presence of $\mathrm{Sr}^{2+}$, delayed aEPSCs were associated with each stimulus in addition to the evoked eEPSCs because of synchronous release. Isoproterenol increased eEPSC amplitude relative to the controls $(207.7 \pm 14.1$ and $332.9 \pm 24.6 \mathrm{pA} ; n=10 ; p<0.0006$, Welch's test; Fig. $5 A, B)$ and the aEPSC mean frequency $(10.0 \pm 1.1$ and $14.5 \pm 1.5 \mathrm{~Hz}$; $n=10 ; p=0.0264$, Student's $t$ test; Fig. $5 C, D)$. Moreover, while it changed the aEPSC frequency distribution $(p<0.0001$, Kolmogorov-Smirnov test; Fig. $5 E$ ), it did not affect the aEPSC mean amplitude $(9.50 \pm 0.20 \mathrm{pA}, n=301$; and $9.80 \pm 0.16 \mathrm{pA}$, $n=435 ; p=0.2385$, Student's $t$ test; Fig. $5 F$ ) or its amplitude distribution ( $p=0.0799$, Kolmogorov-Smirnov test; Fig. $5 G$ ). Similarly, 8pCPT enhanced the eEPSC mean amplitude (198.2 \pm 10.8 and $340.2 \pm 25.5 \mathrm{pA} ; n=10 ; p<0.0003$, Welch's test; Fig. $5 H, I)$, and it increased the mean frequency of aEPSCs $(9.30 \pm 0.6$ and $16.2 \pm 1.3 \mathrm{~Hz} ; n=10 ; p=0.0003$, Welch's test; Fig. 5J,K). This Epac activator also modified the aEPSC frequency 


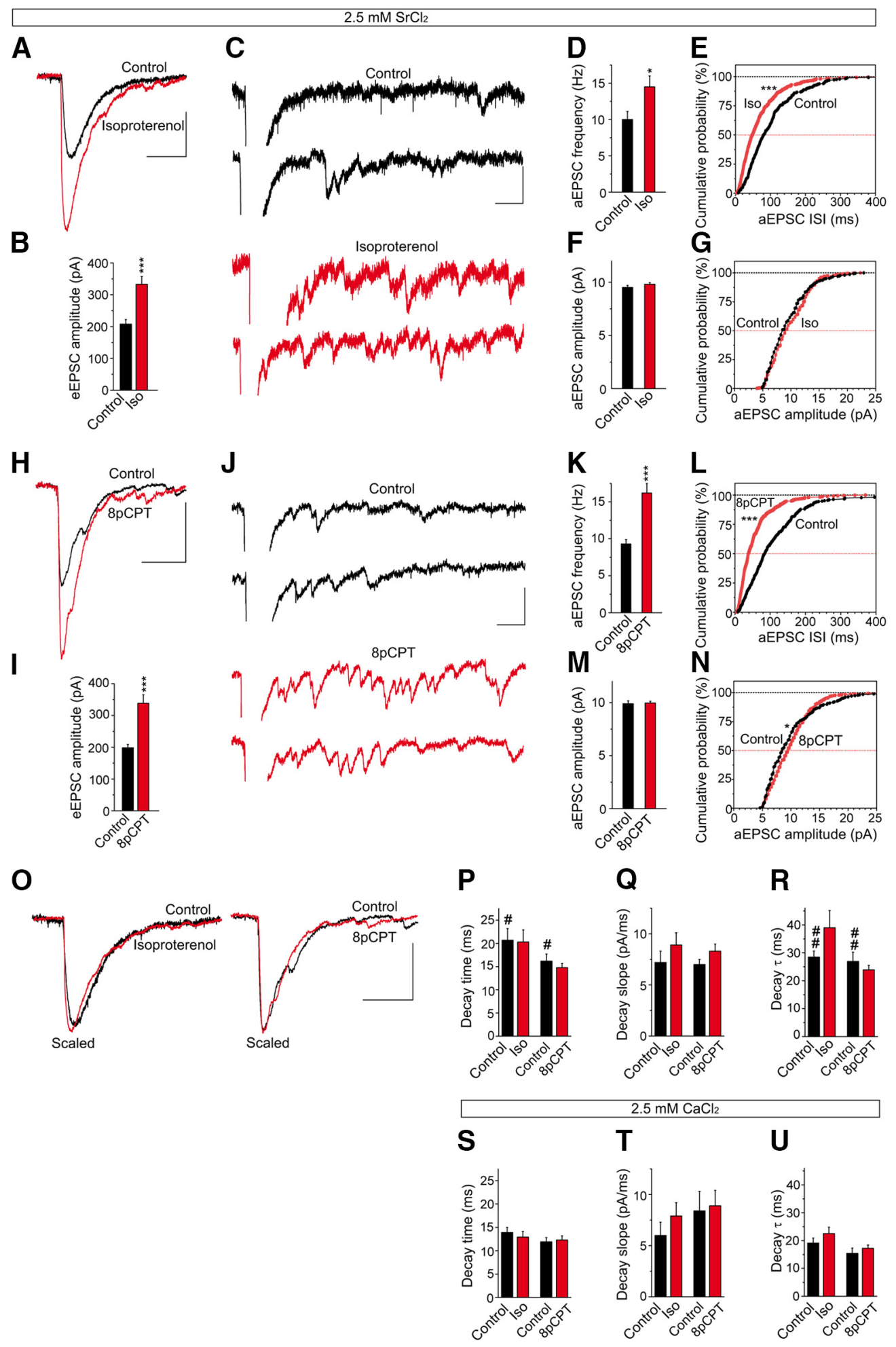

Figure 5. Isoproterenol and 8pCPT enhance the frequency but not the amplitude of the asynchronous release events. $\boldsymbol{A}, \boldsymbol{H}$, The effects of isoproterenol (100 $\mu \mathrm{m}, 10 \mathrm{~min})$ and $8 \mathrm{p} C P T$ ( $50 \mu \mathrm{m}$, $10 \mathrm{~min})$ on eEPSCS recorded in the presence of $S r^{2+}(2.5 \mathrm{~mm}) . \boldsymbol{C}$, J, Individual traces showing asynchronous release events in control conditions (black) and after isoproterenol (C, red) or 8pCPT treatment $(J$, red). $B, I$, Quantification of the effects of isoproterenol $(n=10$ cells $/ 10$ slices $/ 8$ mice, $t=4.416, \mathrm{df}=14)$ and $8 p$ CPT $(n=10$ cells $/ 10$ slices $/ 8 \mathrm{mice}, t=5.128$. $\mathrm{df}=12)$ on eEPSC amplitude. $\boldsymbol{D}-\boldsymbol{G}, \boldsymbol{K}-\boldsymbol{N}$, Quantification of the changes in aEPSC frequency and amplitude induced by isoproterenol $(\boldsymbol{D}-\boldsymbol{G})$ and $8 \mathrm{pCPT}(\boldsymbol{K}-\boldsymbol{N})$. The aEPSC frequency was enhanced by isoproterenol $(\boldsymbol{D}, \boldsymbol{E}: n=10$ cells/10 slices/8 mice, $t=2.419, \mathrm{df}=18)$ and $8 \mathrm{pCPT}(\boldsymbol{K}, \boldsymbol{L}: n=10$ cells/10 slices/7 mice, $t=5.073, \mathrm{df}=12)$, without changing the aEPSC amplitude in isoproterenol $(\boldsymbol{F}, \mathbf{G}: n=10$ cells/10 slices/7 mice, $t=1.180, \mathrm{df}=734)$ and $8 \mathrm{pCPT}(\boldsymbol{M}, \boldsymbol{N}: n=10$ cells/10 slices/7 mice, $t=0.2137, \mathrm{df}=484)$. Calibration: $\boldsymbol{A}, \boldsymbol{H}, 100 \mathrm{pA}$ and $50 \mathrm{~ms} ; \boldsymbol{C}, \boldsymbol{J}, 25 \mathrm{pA}$ and $50 \mathrm{~ms} . \boldsymbol{O}$, Effects of isoproterenol and 8pCPT on eEPSC kinetics in the presence of $\mathrm{Sr}^{2+}$ analyzed in scaled representations. $\boldsymbol{P}$, The decay time (ms) was not altered by isoproterenol $(t=0.1109, \mathrm{df}=18)$ or by $8 \mathrm{pCPT}(t=0.8003, \mathrm{df}=18)$. $\boldsymbol{Q}$, The decay slope pA/ms was not modified by isoproterenol $(t=1.033, \mathrm{df}=18)$ or by $8 \mathrm{pCPT}(t=1.51, \mathrm{df}=18) . \boldsymbol{R}$, The decay tau (ms) was not changed by isoproterenol $(t=1.628, \mathrm{df}=11)$ or by $8 \mathrm{pCPT}(t=0.818, \mathrm{df}=13) . \mathbf{S}-\boldsymbol{U}$, Effect of isoproterenol and $8 \mathrm{pCPT}$ on eEPSC kinetics in the presence of $\mathrm{Ca}^{2+} . \mathbf{S}$, The decay time was not altered by isoproterenol $(t=0.6143, \mathrm{df}=24)$ or by 8pCPT $(t=0.3143 \mathrm{df}=22) . \boldsymbol{T}$, The decay slope $(\mathrm{pA} / \mathrm{ms})$ was not changed by isoproterenol $(t=1.033, \mathrm{df}=24)$ or by $8 \mathrm{p} C \mathrm{PT}(t=0.2965, \mathrm{df}=22) . \boldsymbol{U}, \mathrm{The}$ decay tau (ms) was not modified by isoproterenol $(t=1.164, \mathrm{df}=24)$ or by $8 \mathrm{pCPT}(t=0.4317, \mathrm{df}=22)$. Replacing $\mathrm{Ca}^{2+}$ with $\mathrm{Sr}^{2+}$ increased the control decay time $(t=2.267, \mathrm{df}=12)$ and control decay tau $(t=3.409, \mathrm{df}=21)$. Calibration: $\mathbf{0}, 100 \mathrm{pA}$ and $50 \mathrm{~ms}$. The data represent the mean \pm SEM. 
distribution ( $p<0.0001$, Kolmogorov-Smirnov test; Fig. $5 L$ ), yet it did not change the aEPSC mean amplitude (9.89 \pm 0.28 , $n=280$; and $9.96 \pm 0.17 \mathrm{pA}, n=485 ; p=0.8309$, Welch's test; Fig. $5 M)$, although it did slightly modify the cumulative probability distribution ( $p=0.0132$, Kolmogorov-Smirnov test; Fig. $5 N$ ). This latter phenomenon was probably related to the effect of Epac on the open-channel probability of postsynaptic AMPARs in PCs (Gutierrez-Castellanos et al., 2017). These experiments indicate that isoproterenol and $8 \mathrm{pCPT}$ potentiate synaptic transmission largely through their presynaptic effects.

The effects of isoproterenol and 8pCPT on eEPSC kinetics in the presence of $\mathrm{Sr}^{2+}$ were analyzed in scaled representations (Fig. 5O). Neither isoproterenol nor 8pCPT modified the decay time (in milliseconds; $p=0.9129$ and $p=0.4340$, respectively, Student's $t$ test; Fig. $5 P$ ), the decay slope (in picoamperes per millisecond; $p=0.3102$ and $p=0.1481$, respectively, Student's $t$ test; Fig. 5Q), or the tau of decay (in milliseconds; $p=0.1319$ and $p=0.4281$, Welch's test; Fig. 5R). The effects of isoproterenol and 8 pCPT on eEPSC kinetics were also analyzed in the presence of $\mathrm{Ca}^{2+}$, with no effect of isoproterenol or $8 \mathrm{pCPT}$ evident on the following parameters: the decay time (in milliseconds; $p=0.545$, Student's $t$ test and $p=0.7563$, respectively, Student's $t$ test; Fig. $5 S$ ), the decay slope (in picoamperes per millisecond; $p=0.3117$ and $p=0.8483$, respectively, Student's $t$ test; Fig. 5T), or the tau of decay (in milliseconds; $p=0.2558$ and $p=0.4317$, respectively, Student's $t$ test; Fig. $5 U$ ). Although replacing $\mathrm{Ca}^{2+}$ with $\mathrm{Sr}^{2+}$ increased the control decay time $(p=0.0427$, Welch's test; Fig. $5 P)$ and the control tau of decay $(p=0.0026$, Student's $t$ test; Fig. 5R).

\section{$\beta 1 A R s$ and Epac are required for PF-PC LTP}

We tested whether $\beta$ AR signaling through Epac proteins participates in presynaptically expressed forms of LTP. At cerebellar granule cell-to-PC synapses, LTP depends on a $\mathrm{Ca}^{2+}$-mediated increase in presynaptic cAMP (Salin et al., 1996), and it requires the AZ protein RIM1 $\alpha$ to enhance transmitter release (Castillo et al., 2002; Lonart et al., 2003). Stimulation at $10 \mathrm{~Hz}$ for $10 \mathrm{~s}$ induced PF-PC LTP in naive cerebellar slices (from $99.7 \pm 6.7 \%$ to $149.2 \pm 17.7 \% ; n=16 ; p=0.0013$, Welch's test; Fig. $6 A, B$ ), and the presynaptic origin of this LTP was evident through the decrease in the PPR (from $1.79 \pm 0.08$ to $1.51 \pm 0.04 ; n=16$; $p=0.0049$, Welch's test; Fig. $6 E, F)$. Although Rp-8-CPT-cAMPS has been used to assess the involvement of PKA in PF-PC LTP, this cAMP analog also inhibits Epac proteins (Chen et al., 2014). Thus, we tested the contribution of $\beta$ ARs to PF-PC LTP using the broad $\beta \mathrm{AR}$ antagonist propranolol, which prevented $\mathrm{PF}-\mathrm{PC}$ LTP (from $98.9 \pm 4.8 \%$ to $96.5 \pm 5.4 \%$; $n=12 ; p=0.7429$, Student's $t$ test; Fig. $6 A, B$ ). PF-PC LTP was also prevented by the specific $\beta 1 \mathrm{AR}$ antagonist metoprolol (from to $102.7 \pm 3.5 \%$ to $98.3 \pm 5.1 \% ; n=10 ; p=0.4860$, Student's $t$ test; Fig. $6 A, B)$ as did the selective Epac2 inhibitor ESI 05 (from 103.6 $\pm 5.1 \%$ to $96.3 \pm 6.9 \% ; n=11 ; p=0.405$, Student's $t$ test; Fig. $6 C, D)$. By contrast, PF-PC LTP was insensitive to the PKA inhibitors H-89 (from $103.1 \pm 3.8 \%$ to $161.2 \pm 19.0 \% ; n=13 ; p=0.0111$, Welch's test) and KT5720 (from $103.8 \pm 5.5 \%$ to $179.5 \pm 16.4 \%$; $n=10$; $p=0.0014$, Welch's test; Fig. $6 C, D$ ). Thus, PF-PC LTP requires $\beta$ AR signaling and the activity of Epac proteins.

Further evidence that $\beta$ ARs participate in PF-PC LTP was obtained in occlusion experiments. The $\beta \mathrm{AR}$ agonist isoproterenol increased EPSC amplitude (from $98.5 \pm 5.4 \%$ to $190.7 \pm$ $19.6 \% ; n=12 ; p=0.0007$, Welch's test; Fig. $6 I, J)$, yet a subsequent $10 \mathrm{~Hz}$ stimulation failed to further potentiate synaptic transmission (from $190.7 \pm 19.6 \%$ to $191.8 \pm 17.1 \% ; p=0.9666$, Student's $t$ test; Fig. 6I,J). Likewise, the Epac agonist 8pCPT induced a sustained increase in EPSC amplitude (from 98.4 $\pm 4.1 \%$ to $194.3 \pm 12.7 \% ; n=13 ; p<0.0001$, Welch's test; Fig. $6 K, L)$, which similarly occluded potentiation by a subsequent $10 \mathrm{~Hz}$ stimulation (from $194.3 \pm 12.7 \%$ to $205.7 \pm 18.9 \% ; n=13 ; p=0.6212$, Student's $t$ test; Fig. $6 K, L)$. Thus, prior activation of $\beta$ ARs or Epac proteins occluded tetanus-induced PF-PC LTP, suggesting that Epac-dependent signaling by $\beta$ ARs is involved in PF-PC LTP.

\section{PF-PC LTP is absent in Epac2 $2^{-/-}$mice, in which isoproterenol fails to enhance SV docking}

The presynaptic action of Epac at PFs is consistent with the abundance of Epac2 in the cerebellum (Kawasaki et al., 1998), and, thus, we studied synaptic transmission in Epac2 ${ }^{-1-}$ mice to further assess the role of Epac2 in PF-PC LTP (Shibasaki et al., 2007). PF LTP was absent in cerebellar slices from Epac2 $2^{-l-}$ mice (from $100.6 \pm 4.1 \%$ to $98.7 \pm 2.0 \%$; $n=15 ; p=0.6812$, Welch's test), whereas a $10 \mathrm{~Hz}$ stimulation for $10 \mathrm{~s}$ did induce PF-PC LTP in WT slices (from $101.3 \pm 5.0 \%$ to $169.1 \pm 15.6 \%$; $n=13 ; p=0.0025$, Welch's test; Fig. 7A,B). PF LTP was associated with a decrease in the EPSC2/EPSC1 PPR (from $1.80 \pm 0.07$ to $1.52 \pm 0.05 ; p=0.0023$ Student's $t$ test; Fig. $7 C$ ), a phenomenon not observed in Epac2 $^{-1-}$ slices (1.75 \pm 0.06 and $1.73 \pm 0.08$; $p=0.8429$, Student's $t$ test).

The presynaptic origin of PF LTP was further assessed by replacing $\mathrm{Ca}^{2+}$ with $\mathrm{Sr}^{2+} 30 \mathrm{~min}$ after a $10 \mathrm{~Hz}$ stimulation. In the presence of $\mathrm{Sr}^{2+}$, LTP increased the mean frequency of aEPSCs $(9.72 \pm 0.76, n=6$; and $14.43 \pm 0.77 \mathrm{~Hz}, n=7 ; p=0.0012$, Student's $t$ test; Fig. $7 D, E)$ and altered the aEPSC frequency distribution ( $p=0.0011$, Kolmogorov-Smirnov; Fig. $7 F$ ) in WT but not in Epac2 $^{-1-}$ slices $[10.0 \pm 1.00, n=8$, and $9.21 \pm 0.60 \mathrm{~Hz}$, $n=8, p=0.5039$ Student's $t$ test (Fig. $7 E$ ); and $p=0.2539$, Kolmogorov-Smirnov test (Fig. $7 F$ )]. By contrast, there were no changes in the aEPSC mean amplitude in WT slices undergoing LTP under these conditions ( $10.55 \pm 0.31, n=175$; and $10.03 \pm$ $0.29 \mathrm{~Hz}, n=303 ; p=0.2213$, Welch's test; Fig. $7 D, G)$, although there was a mild reduction in the aEPSC amplitude in the cumulative probability plots $(p=0.0008$, Kolmogorov-Smirnov test; Fig. $7 H$ ). Similarly, there was no change in aEPSC mean amplitude during LTP in Epac2 ${ }^{-1-}$ slices $(9.96 \pm 0.33, n=241$; and $9.76 \pm 0.33 \mathrm{pA}, n=220 ; p=0.6847$, Student's $t$ test; Fig. $7 G$ ) or in the amplitude distribution of aEPSC $(p=0.949$, KolmogorovSmirnov test; Fig. $7 H$ ). Thus, PF LTP largely involved changes in aEPSC frequency, providing further evidence of its presynaptic origin.

We determined to what extent the lack of PF-PC LTP in Epac2 $^{-1-}$ mice was a result of changes in vesicle docking assessed by EM. Chemical LTP was induced by incubating cerebellar slices with isoproterenol $(100 \mu \mathrm{M})$ for $10 \mathrm{~min}$, and the SV distribution was then determined in fixed slices by EM. Isoproterenolenhanced SV docking in WT slices [from $4.21 \pm 0.12(n=182)$ to $5.15 \pm 0.12]$ synaptic vesicles/AZ profile $(n=168 ; p<0.001$, ANOVA Bonferroni's test; Fig. 7I,J,M). The absence of PF-PC LTP was associated with a failure of isoproterenol to increase SV docking in Epac2 ${ }^{-/-}$slices, which ranged from to $4.35 \pm 0.12$ synaptic vesicles/AZ profile $(n=160)$ in the presence of isoproterenol to $4.64 \pm 0.13$ synaptic vesicles/AZ profile $(n=180)$ in its absence $(p>0.05$, ANOVA with Bonferroni's test; Fig. $7 K, L, P)$.

Docked and primed SVs are heterogeneous, and the following two subpopulations can be distinguished: loosely docked SVs located $8 \mathrm{~nm}$ from the AZ membrane because of partial zippering of SNARE complexes; and fully primed and tightly docked 

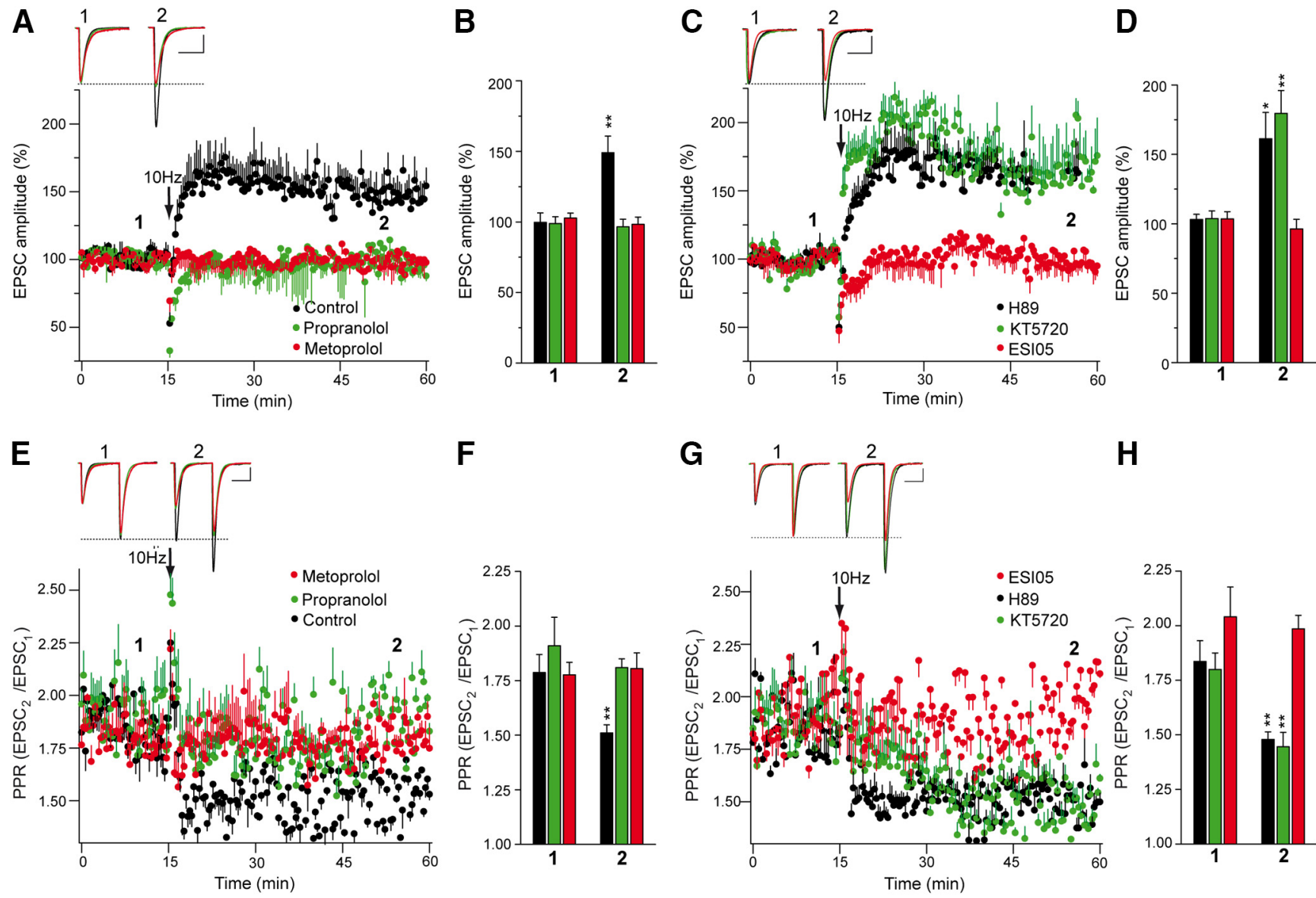

H
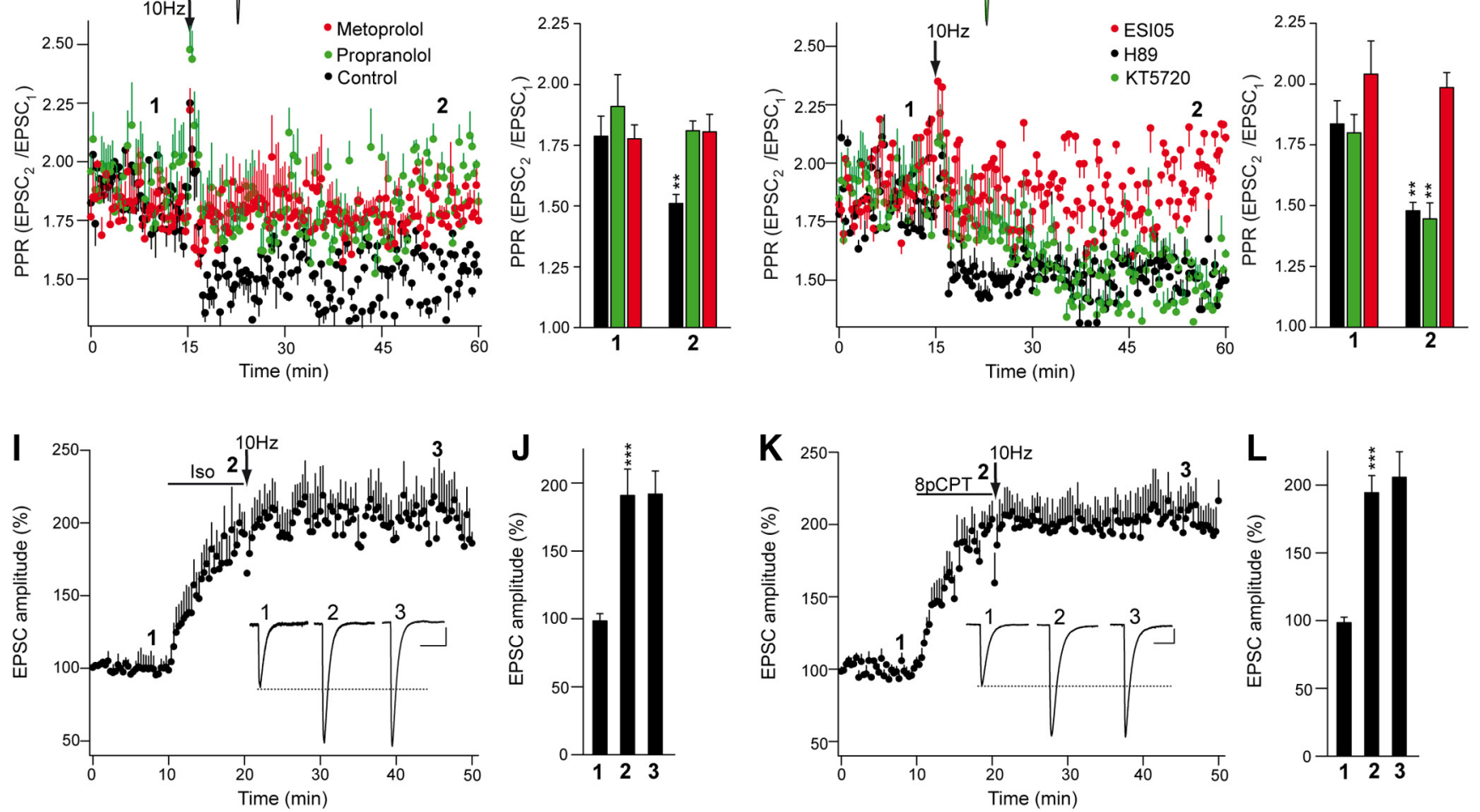

Figure 6. $\beta$ AR and Epac activation is required for PF-PC LTP. A, C, A $10 \mathrm{~Hz} 10 \mathrm{~s}$ stimulation induced a sustained increase in EPSC amplitude in control and in KT-5720-treated (2 $\mu \mathrm{m}$, $30 \mathrm{~min}$ prior $10 \mathrm{~Hz}$ stimulation) or $\mathrm{H}-89$-treated $(10 \mu \mathrm{m}, 30 \mathrm{~min}$ ) slices. Similar increases were absent in slices treated with the Epac inhibitor ESI 05 (10 $\mu \mathrm{m}, 30 \mathrm{~min})$ or with the $\beta$ AR antagonists propranolol (100 $\mu \mathrm{m}, 30 \mathrm{~min})$ or metoprolol $(60 \mu \mathrm{m}, 30 \mathrm{~min}) . \boldsymbol{B}, \mathbf{D}$, Quantification of the changes in EPSC amplitude measured 40 min after stimulation (2) in control slices ( $n=16$ cells/ 16 slices/14 mice, $t=3.671, \mathrm{df}=23)$, propranolol-treated slices $(n=12$ cells $/ 12$ slices $/ 8$ mice, $t=0.3322, \mathrm{df}=22)$, metoprolol-treated slices $(n=10$ cells $/ 10$ slices $/ 5$ mice, $t=0.7113$, $\mathrm{df}=18$ ), H-89-treated slices ( $n=13$ cells/13 slices/6 mice, $t=2.999, \mathrm{df}=12)$, KT-5720-treated slices ( $n=10$ cells/10 slices/7 mice, $t=4352$, df $=10)$, and ESI 05-treated slices $(n=11$ cells/ 11 slices $/ 9$ mice, $t=0.8508, \mathrm{df}=20$ ) relative to the respective values before stimulation (1). $\boldsymbol{E}, \mathbf{G}$, (hanges in the PPR (EPSC2/EPSC1) induced by $10 \mathrm{~Hz}$ stimulation in the conditions shown in $\boldsymbol{A}$ and $\boldsymbol{C}$, respectively. $\boldsymbol{F}, \boldsymbol{H}$, Quantification of the changes in PPR $40 \mathrm{~min}$ after a $10 \mathrm{~Hz}$ stimulation in control $[t=3.13$, df $=22$ compared with (1)], and in the presence of propranolol $[t=0.7352, \mathrm{df}=13$ compared with (1)], metoprolol $[t=0.2169, \mathrm{df}=18$ compared with (1)], $\mathrm{H}-89$ [ $t=3448, \mathrm{df}=14$ compared with (1)], KT-5720 [t=3.387, $\mathrm{df}=18, \mathrm{compared}$ with (1)], or ESI $05[t=3.3283, \mathrm{df}=11$, compared with (1)]. EPSC sample traces $(\boldsymbol{A}, \boldsymbol{C}, \boldsymbol{E}, \boldsymbol{G})$ represent the mean of six consecutive EPSCs at $0.05 \mathrm{~Hz}$ taken before and $40 \mathrm{~min}$ after $10 \mathrm{~Hz}$ stimulation. Calibration: $50 \mathrm{pA}$ and $15 \mathrm{~ms}$. $\boldsymbol{I}, \boldsymbol{K}$, The $\beta$ AR agonist isoproterenol (10 min, $100 \mu \mathrm{m} ; \boldsymbol{I})$ and Epac activator 8pCPT (50 $\mu \mathrm{m}, 10 \mathrm{~min} ; \boldsymbol{K})$ induced a sustained increase in EPSC amplitude that occludes the $10 \mathrm{~Hz}$ induced LTP. J, L, Quantification of the changes in EPSC amplitude induced by isoproterenol $(\boldsymbol{J})$ and $8 \mathrm{p} C \mathrm{PT}(\boldsymbol{L})$ followed by $10 \mathrm{~Hz}$ stimulation. The data were measured 10 min after isoproterenol/8p(PT application (2) $[n=12$ cells/12 slice/6 mice, $t=453.5, \mathrm{df}=12$ and $n=13$ cells/13 slices/6 mice, $t=7.186, \mathrm{df}=14$, respectively, compared with (1)]. The data were also measured $30 \mathrm{~min}$ after $10 \mathrm{~Hz}$ stimulation (3) $[t=0.04,229, \mathrm{df}=22$ and $t=0.5006, \mathrm{df}=24$, respectively, compared with (2)]. EPSC sample traces $(\boldsymbol{I}, \boldsymbol{K})$ represent the mean of six consecutive EPSCS at $0.05 \mathrm{~Hz}$ taken before (1) and $10 \mathrm{~min}$ after (2) isoproterenol/8pCPT treatment, and $30 \mathrm{~min}$ after $10 \mathrm{~Hz}$ stimulation (3). The data represent the mean \pm SEM.

SVs in which SNARE complex zippering has progressed further and, therefore, these SVs are closer to the AZ membrane $(<5 \mathrm{~nm}$; Fernández-Busnadiego et al., 2013; Imig et al., 2014; Neher and Brose, 2018). To distinguish loosely from tightly docked and primed SVs, we studied the distribution of SVs within a distance of $5 \mathrm{~nm}$ and $5-10 \mathrm{~nm}$ from the $\mathrm{AZ}$ membrane. Isoproterenol increased the number of SVs within $5 \mathrm{~nm}$ from the AZ membrane in WT slices [from $3.31 \pm 0.12(n=182)$ to $4.04 \pm$ 

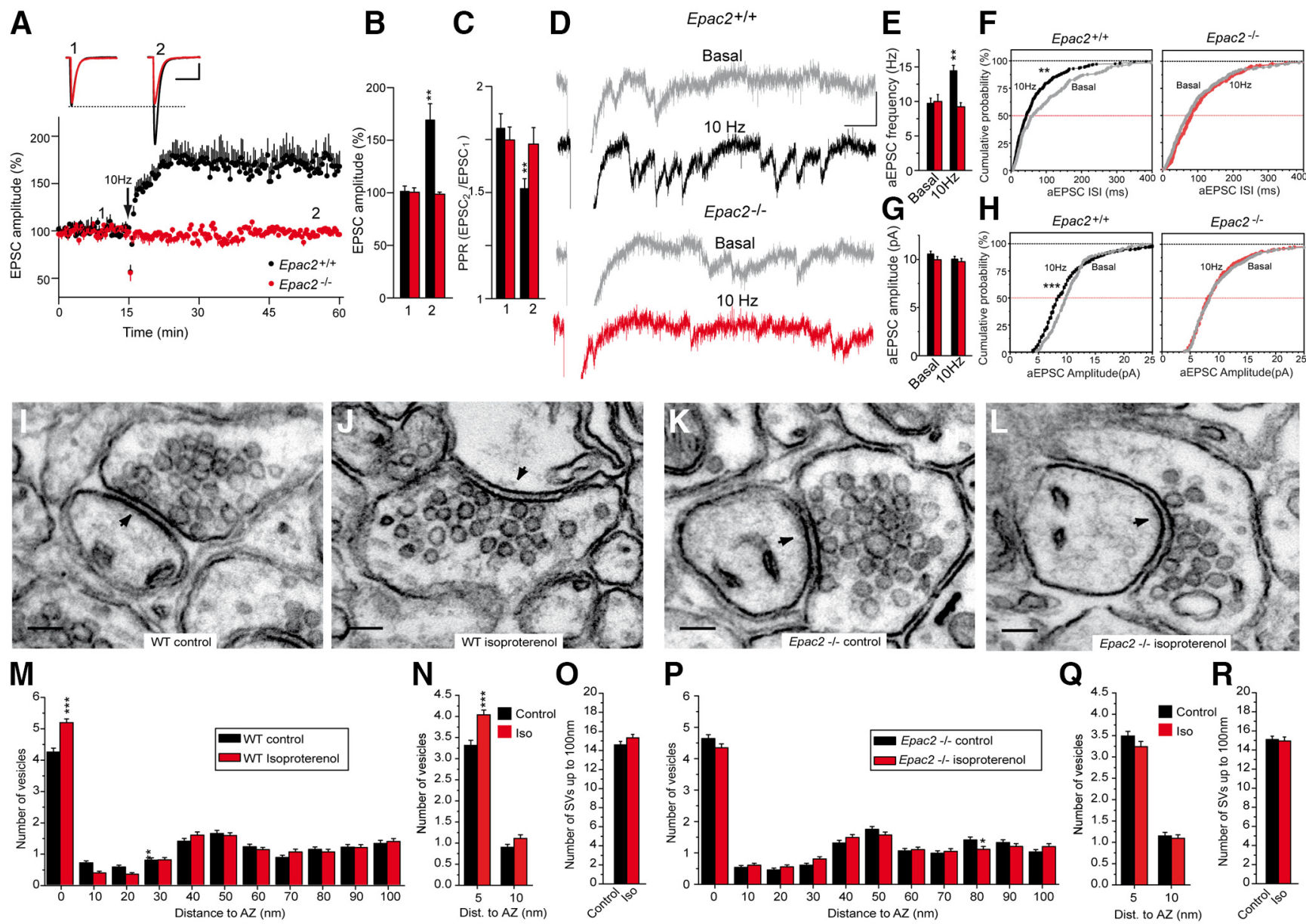

Figure 7. Epac2 ${ }^{-1-}$ slices lack PF-PC LTP, and they display no isoproterenol induced increase in SV docking. A, A $10 \mathrm{~Hz}, 10 \mathrm{~s}$ stimulation induced a sustained increase in the EPSC amplitude in WT cerebellar slices that was absent in slices from Epac2 ${ }^{-1}$ littermates. B, Quantification of the changes in EPSC amplitude measured 40 min after stimulation (2) in slices from WT ( $n=13$ cells/13 slices/6 mice, $t=3.745, \mathrm{df}=13)$ or Epac2 ${ }^{-1-}$ mice $(n=15$ cells/15 slices/8 mice, $t=0.4169, \mathrm{df}=15)$ compared with the values before stimulation (1). C, Quantification of the changes in the PPR measured $40 \mathrm{~min}$ after stimulation (2) in slices from WT $(t=3.403, \mathrm{df}=24)$ and $E p a c 2^{-1-}$ mice $(t=0.2000, \mathrm{df}=28)$ compared with the values before stimulation $(1)$. $\boldsymbol{D}$, The aEPSCs induced when replacing $\mathrm{Ca}^{2+}$ with $\mathrm{Sr}^{2+}(2.5 \mathrm{~mm}) 30 \mathrm{~min}$ after $10 \mathrm{~Hz}$ stimulation. After $5 \mathrm{~min}$, individual traces showing aEPSCs were analyzed $(2 \mathrm{~min})$ in basal (gray) and stimu-

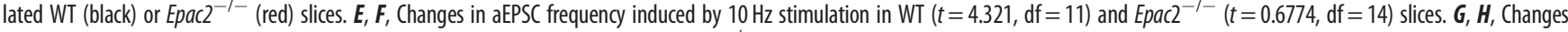
in aEPSC amplitude induced by $10 \mathrm{~Hz}$ stimulation in WT $(t=1.225, \mathrm{df}=424)$ and Epac2 ${ }^{-I-}(t=0.4063, \mathrm{df}=459)$ slices. $I, J$, Isoproterenol $(100 \mu \mathrm{m}, 10 \mathrm{~min})$ increases $S V$ docking in WT mice. $M$, Quantification of the isoproterenol induced an increase in SV docking in WT mice. $\mathbf{N}$, Isoproterenol increases the number of SVs $0-5 \mathrm{~nm}$ from the AZ membrane without changing the SVs 5-10 nm from the AZ membrane in WT slices. $\mathbf{O}$, Isoproterenol treatment did not change the total number of SVs up to $100 \mu \mathrm{m}$ from the AZ in WT slices. $\boldsymbol{K}, \boldsymbol{L}$, Isoproterenol treatment fails to

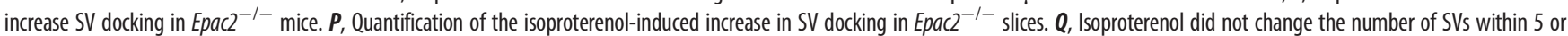
5-10 nm from the AZ membrane in Epac2 ${ }^{-1-}$ slices. $\boldsymbol{R}$, Isoproterenol treatment did not change the total number of SVs up to $100 \mu \mathrm{m}$ from the AZ membrane in Epac $2^{-1-}$ slices. Calibration: $A, 50 \mathrm{pA}$ and $15 \mathrm{~ms} ; \mathbf{D}, 20 \mathrm{pA}$ and $40 \mathrm{~ms}$. Scale bars: $I-L, 100 \mathrm{~nm}$. The data represent the mean \pm SEM.

$0.11(n=168)]$ synaptic vesicles/AZ profile $(p<0.001$, ANOVA Bonferroni's test; Fig. $7 N$ ) without affecting the number of SVs located $5-10 \mathrm{~nm}$ from the AZ membrane (from $0.90 \pm 0.07$ to $1.11 \pm 0.08$ synaptic vesicles/AZ profile; $p>0.05$, ANOVA with Bonferroni's test; Fig. $7 N$ ). Conversely, no change in the number of SVs $<5 \mathrm{~nm}$ from the AZ membrane was observed in Epac2 ${ }^{-/-}$slices under control conditions relative to the WT slices $(3.49 \pm 0.11$; $n=180 ; p>0.05$, ANOVA with Bonferroni's test; Fig. 7Q), and, moreover, isoproterenol failed to increase this parameter $(3.24 \pm$ 0.12; $n=160 ; p>0.05$, ANOVA with Bonferroni's test; Fig. 7Q). Similarly, isoproterenol did not alter the SVs $5-10 \mathrm{~nm}$ from the AZ membrane in Epac2 ${ }^{-1-}$ slices $(1.15 \pm 0.08, n=180$; and $1.09 \pm$ $0.08, n=160 ; p>0.05$, ANOVA with Bonferroni's test; Fig. 7Q). Thus, the absence of Epac2 prevents isoproterenol-induced increase in tightly docked and fully primed SVs. In addition, isoproterenol did not alter the total number of SVs within $100 \mu \mathrm{m}$ from the AZ plasma membrane in WT or Epac $2^{-1-}$ slices (Fig. 7O,R). Together, these results indicate that the increase in neurotransmitter release during PF-PC LTP requires the isoproterenol-induced Epac2-dependent recruitment of SVs to the plasma membrane AZ.

\section{PF-PC LTP is associated with an increase in the RRP size that is absent in Epac2 $2^{-/-}$slices}

The number of docked vesicles is strongly correlated to the size of the RRP of SVs (Rosenmund and Stevens, 1996; Schikorski and Stevens, 2001). Since PF-PC LTP is associated with SV docking, we tested whether PF-PC LTP also remodels the size of the SV pools, in particular, increasing the RRP size. The RRP size was calculated from the cumulative amplitude plots as the $y$ intercept from a linear fit of the steady-state values attained during high-frequency trains (Schneggenburger et al., 1999; Gioia et al., 2016). Thus, slices were stimulated at $40 \mathrm{~Hz}$ for $2.5 \mathrm{~s}$ in basal conditions or $30 \mathrm{~min}$ after LTP induction. In WT slices, the RRP size increased after LTP induction from $4347.4 \pm 513.8 \mathrm{pA}$ $(n=18)$ to $8586.9 \pm 848.3 \mathrm{pA}(n=21 ; p=0.012$, Student's $t$ test; Fig. $8 A-D)$. The $10 \mathrm{~Hz}$ stimulation protocol failed to induce LTP 


\section{Epac2 $^{+/+}$}
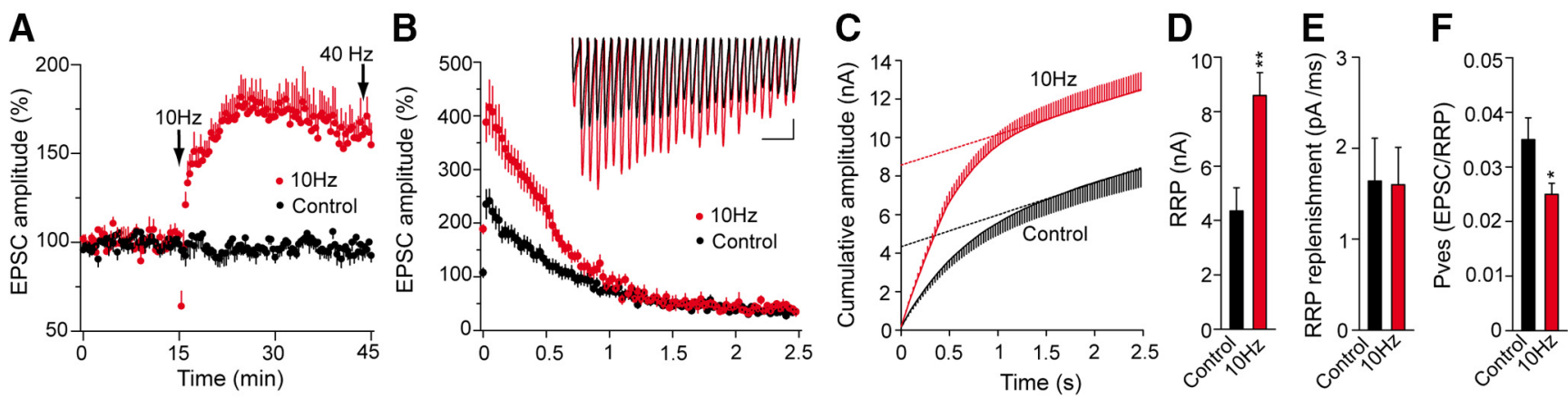

\section{Epac2 $^{-/}$}
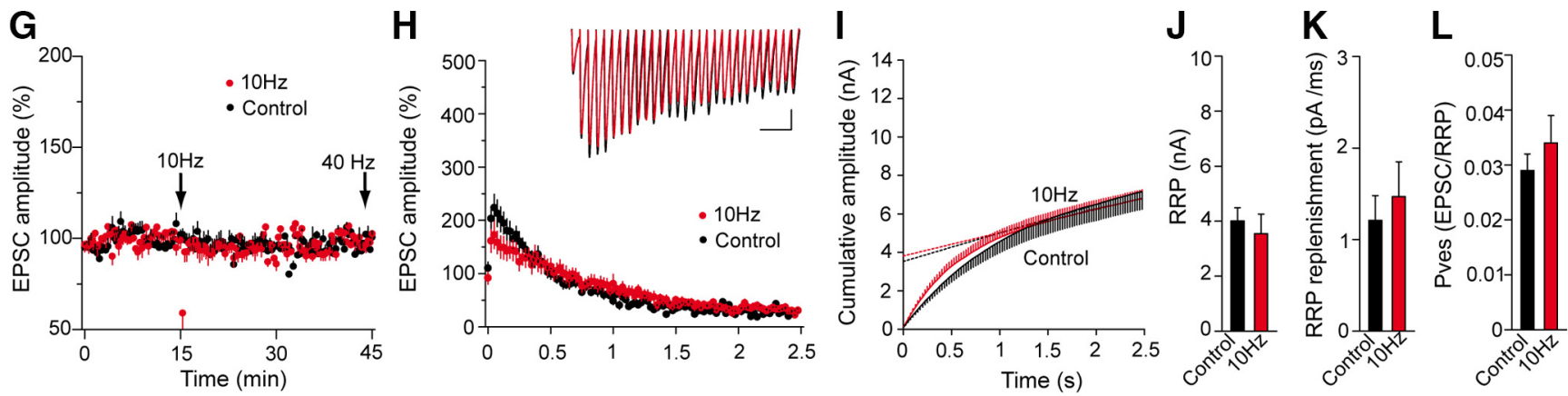

Figure 8. PF-PC LTP is associated with an increase in the RRP size that does not occur in Epac2 $2^{-1-}$ mice. $\boldsymbol{A}, \mathbf{G}$, The RRP size was measured after a train of 100 pulses at $40 \mathrm{~Hz}$ applied 30 min after LTP induction, as well as in control (unstimulated) slices from both WT and Epac2 ${ }^{-1-}$ mice (littermates). $\boldsymbol{B}, \boldsymbol{H}$, EPSC amplitude during the $40 \mathrm{~Hz}$ train, the traces showing individual examples. Calibration: $100 \mathrm{pA}$ and $100 \mathrm{~ms}$. C, I, Cumulative EPSC amplitudes in control and LTP-induced cells. The RRP size was calculated from the cumulative amplitude plots as the $y$ intercept from a linear fit of the steady-state level attained during the high-frequency train. $D, J$, Quantification of the changes in the RRP size induced by a $10 \mathrm{~Hz}$ stimulus in slices from WT (D: control slices, $n=18$ cells/18 slices/8 mice, $10 \mathrm{~Hz}$ stimulated slices, $n=21$ cells/21 slices $/ 9$ mice, $t=3.506, \mathrm{df}=37)$ and Epac2 ${ }^{-1-}$ mice $(J$ : control slices, $n=21$ cells/21 slices $/ 10$ mice, and $10 \mathrm{~Hz}$ stimulates slices, $t=0.5379, \mathrm{df}=39) . \boldsymbol{E}, \boldsymbol{K}$, Quantification of the replenishment rate $(\mathrm{pA} / \mathrm{ms})$ in slices from WT mice $(\boldsymbol{E}: t=0.064, \mathrm{df}=37)$ and Epac2 ${ }^{-1-}$ mice $(\boldsymbol{K}: t=0.5578, \mathrm{df}=$ 40). $\boldsymbol{F}, \boldsymbol{L}$, Quantification of the $p_{\text {ves }}$ in slices from WT mice $(\boldsymbol{F}: t=2.236, \mathrm{df}=25)$ or Epac ${ }^{-1-}$ mice $(\boldsymbol{L}: t=0.8575, \mathrm{df}=37)$. The data represent the mean \pm SEM.

in Epac2 $^{-1-}$ slices (Figs. 7A,B, 8G), and it did not increase the RRP size (control, $4006.4 \pm 481.2 \mathrm{pA}, n=21$; after the $10 \mathrm{~Hz}$ protocol, $3544.5 \pm 711.3 \mathrm{pA}, n=24 ; p=0.5937$, Welch's test; Fig. $8 G-J)$. Moreover, LTP did not change the replenishment rate (in picograms per millisecond) in WT slices (1.64 \pm 0.47 and $1.60 \pm 0.4$, in control and LTP conditions, respectively; $p=$ 0.9490 , Student's $t$ test; Fig. $8 E)$ or Epac $2^{-1-}$ slices $(1.21 \pm 0.27$ and $1.47 \pm 0.38$, in control and LTP, respectively; $p=0.5801$, Welch's test; Fig. $8 K$ ). PF-PC LTP mildly decreased the $p_{\text {ves }}$ in WT slices $(0.035 \pm 0.004$ and $0.025 \pm 0.002$, in control and LTP, respectively; $p=0.0345$, Welch's test; Fig. $8 F$ ), yet the small decrease in $p_{\text {ves }}$ was overcompensated for by the large increase in the RRP size, leading to an increase in the $\mathrm{P}_{\mathrm{r}}$, as evident by the decrease in PPR during PF-PC LTP (Fig. 6E,F). However, the $p_{\text {ves }}$ did not change in Epac2 ${ }^{-1-}$ slices $(0.029 \pm 0.003$ and $0.034 \pm 0.005$, in control and LTP, respectively; $p=0.397$, Welch's test; Fig. $8 L$ ). Thus, $\beta$ AR-mediated signaling through the Epac2 protein increases the size of the RRP of SVs and contributes to PF-PC LTP at cerebellar synapses.

\section{Discussion}

We found here that isoproterenol increases synaptic transmission at PF-PC synapses by a presynaptic mechanism, whereby $\beta 1$ ARs expressed in PF synaptic boutons generate cAMP and activate Epac, enhancing SV docking. Interestingly, presynaptic PF-PC LTP is blocked by the selective $\beta 1 \mathrm{AR}$ antagonist metoprolol and it is not detected in cerebellar slices from Epac2 $^{-1-}$ mice. Furthermore, the increase in the RRP size when synapses are potentiated is not observed in $\mathrm{Epac}^{-/-}$slices. Thus, $\beta$ ARs appear to activate physiologically relevant signaling in presynaptic PF-PC LTP that involves cAMP- and Epac2-dependent modulation of the release machinery.

PF-PC LTP requires an increase in presynaptic cAMP generated by $\mathrm{Ca}^{2+}$-dependent adenylyl cyclase 1 (AC1; Storm et al., 1998). Since PF-PC LTP requires $\beta$ AR activation, it would appear that $\mathrm{ACl}$ activation by $\mathrm{Ca}^{2+}$ alone is insufficient to induce this LTP and that $\mathrm{G}_{\mathrm{s}}$ stimulation is also required, consistent with the stimulation of all $\mathrm{AC}$ isoforms by $\mathrm{G}_{\mathrm{s} \alpha}$ (Sadana and Dessauer, 2009), and with the notion that AC1 is synergistically stimulated by $\mathrm{Ca}^{2+}$ and $\mathrm{G}_{\mathrm{s}}$-coupled receptors (Wayman et al., 1994). The expression of $\beta$ 1ARs in PF boutons near noradrenergic varicosities makes it likely that the PF stimulation that induces PF-PC LTP recruits noradrenergic fibers to release noradrenaline, which in turn activates $\beta$-adrenergic heteroreceptors at PF boutons, enhancing glutamate release. Noradrenergic fibers are distributed throughout the cerebellar cortex, forming varicosities closely apposed to PF-PC contacts on PC dendrites (Bloom et al., 1971; Abbott and Sotelo, 2000). The finding that $\beta$ AR activation is required for PF-PC LTP is consistent with the presynaptic actions of these receptors at other synapses, as follows: (1) $\beta$ ARs increase cAMP and potentiate glutamate release in cerebrocortical synaptosomes (Herrero and Sánchez-Prieto, 1996; Millán et al., 2002; Ferrero et al., 2013, 2016); (2) $\beta$ AR activation brings SVs 
closer to the plasma membrane (Ferrero et al., 2013) and prevents the presynaptic silencing induced by cannabinoid type 1 receptors in cerebellar granule cells (Alonso et al., 2017); (3) $\beta$ ARs potentiate synaptic transmission through a presynaptic mechanism (Parfitt et al., 1992; Huang et al., 1996; Huang and Hsu, 2006; Ji et al., 2008); and (4) $\beta$ ARs facilitate the induction of other cAMP-dependent forms of presynaptic LTP (Wójtowicz et al., 2010; Ul Haq et al., 2016). Thus, $\beta \mathrm{AR}$ activation recapitulates forskolin-induced enhancement of synaptic transmission (Chavez-Noriega and Stevens, 1994; Chen and Regehr, 1997; Sakaba and Neher, 2001; Kaneko and Takahashi, 2004), and these receptors constitute part of the physiologically relevant signaling involved in the activation of cAMP-dependent endogenous pathways that potentiate neurotransmitter release (Ferrero et al., 2013, 2016). Furthermore, noradrenaline enhances PC excitability in vivo because of an increase in the excitatory input from PFs (Guo et al., 2016).

Our pharmacological data with PKA inhibitors (H-89 and KT-5720) do not support a role of PKA in PF-PC LTP, while both pharmacological Epac2 inhibition (ESI 05) and activation (8pCPT), as well as genetic depletion of Epac2, strongly support the requirement of Epac2 for PF-PC LTP. It is important to note that several studies of PKA and LTP used synapses that developed in vitro, such as cultured granular neurons (Linden and Ahn, 1999; Lonart et al., 2003), and that the functional properties of these synapses are likely to be different from synapses in mature slices. In addition, PF-PC LTP in cerebellar slices was blocked by the PKA inhibitor Rp-8-CPT-cAMPS (Salin et al., 1996), a compound that also inhibits Epac proteins (Zieba et al., 2011; Chen et al., 2014). The search for PKA substrates involved in PF-PC LTP has also produced conflicting results. In one study, RIM1 $\alpha$ phosphorylation by PKA at Ser- 413 was seen to be essential for LTP in paired recordings of cerebellar granule cells and PCs in culture (Lonart et al., 2003). However, this conclusion has been questioned as PF-PC LTP remains intact in knock-in mice carrying a Ser-413 mutated to alanine (Kaeser et al., 2008). Finally, Epac2 plays an essential role in other forms of cAMP-dependent LTP expressed presynaptically as the increase in neurotransmitter release is associated with the hippocampal mossy fiber LTP (Fernandes et al., 2015).

Our data support a key role for Epac2 in the $\beta$ AR potentiation of neurotransmitter release and presynaptic PF-PC LTP. Epac activation increases evoked EPSC amplitude and occludes $10 \mathrm{~Hz}$ induced PF-PC LTP. In addition, PF-PC LTP is blocked by the Epac2-specific inhibitor ESI 05 and is not detected in Epac2 $^{-1-} \mathrm{KO}$ mice. A presynaptic effect of Epac at PFs is consistent with the abundance of Epac2 in the cerebellum (Kawasaki et al., 1998). Epac proteins mediate many responses to presynaptic cAMP in non-neuronal (Ozaki et al., 2000) and neuronal systems, including neurotransmitter release (Kaneko and Takahashi, 2004; Gekel and Neher, 2008; Yang et al., 2012; Ferrero et al., 2013, 2016), SV recruitment (Sakaba and Neher, 2003; Ramírez-Franco et al., 2014; Alonso et al., 2017), and presynaptic plasticity (Fernandes et al., 2015; Tong et al., 2017). The priming activity of Munc13 (Ma et al., 2011) plays a key role in SV docking through assembly of the Munc13-Rim1-Rab3 complex (Dulubova et al., 2005) and SNARE complex. Munc13-1 forms supramolecular self-assemblies that serve as independent release sites (Sakamoto et al., 2018) through which phospholipase C (PLC)-coupled receptors (Bauer et al., 2007; Martín et al., 2010) enhance the RRP size (Martín et al., 2018). $\beta$ ARs and Epac also activate PLC, translocate Munc13-1, enhance Rab3A-RIM1 $\alpha$ interaction, and increase SV docking (Ferrero et al., 2013). However, how a $\mathrm{G}_{\mathrm{s}}$-coupled receptor like $\beta \mathrm{AR}$ and a cAMP target like Epac activate PLC and Munc13-1 proteins is unlikely to be straightforward. Epac proteins are guanine nucleotide exchange factors for the small GTPases Rap1 and Rap2 (Kawasaki et al., 1998), which can bind to and activate PLC- $\varepsilon$ in HEK293 cells (Schmidt et al., 2001). Significantly, PLC- $\varepsilon$ is expressed in the brain (Thomas et al., 1991; Kelley et al., 2001), and diacylglycerol (DAG) can increase SV docking and priming through the activation of Munc13 proteins (Rhee et al., 2002).

We found that $\beta$ ARs strongly potentiate synaptic transmission and that this effect is associated with an increase in docked SVs. Specifically, $\beta$ ARs enhance the docking of SVs $0-5 \mathrm{~nm}$ from AZ membrane, SVs that are tightly docked and fully primed, and thus, release ready (Fernández-Busnadiego et al., 2013; Imig et al., 2014; Neher and Brose, 2018; Maus et al., 2020). The docked SVs are closely correlated with the RRP size (Rosenmund and Stevens, 1996; Schikorski and Stevens, 2001), although not all docked vesicles are released and some undocked vesicles contribute to the RRP (Kaeser and Regehr, 2017). EM also has some limitations as it provides a static image of a section of the synapse and chemical fixation may alter the SV distribution (Maus et al., 2020). It is possible that the strong potentiation of synaptic transmission mediated by $\beta$ ARs is not fully accounted for by the weak effect on docking and that a postdocking effect enhancing $\mathrm{Ca}^{2+}$-dependent fusion could also be involved. Thus, forskolin increases the $\mathrm{Ca}^{2+}$ sensitivity of transmitter release induced with weak $\mathrm{Ca}^{2+}$-uncaging flashes $(\sim 0.5-1$ $\mu \mathrm{M} \mathrm{Ca}{ }^{2+}$; Yao and Sakaba, 2010). A change in $\mathrm{Ca}^{2+}$-dependent fusion would be consistent with an increase in the $\mathrm{P}_{\mathrm{r}}$, as seen by the decrease in the PPR. Indeed, the decrease in PPR mediated by noradrenaline, isoproterenol, $8 \mathrm{pCPT}$, and $10 \mathrm{~Hz}$ LTP seen here should not only be regarded as an indication of a presynaptic change but also, as an increase in the initial $\mathrm{P}_{\mathrm{r}}$ (Branco and Staras, 2009). Noradrenaline also modulates release by increasing the $\mathrm{Ca}^{2+}$ sensitivity of vesicle fusion (Yawo, 1996, 1999). Thus, $\beta$ AR-mediated potentiation of neurotransmitter release involves a docking effect, and it may also involve a post-docking component (Chen and Regehr, 1997; Kaneko and Takahashi, 2004). However, the decrease in the mean $p_{\text {ves }}$ during PF-PC LTP suggests a limited influence of a change in the $\mathrm{Ca}^{2+}$ sensitivity of release in the potentiation of synaptic transmission by $\beta$ ARs. It is important to note that $p_{\text {ves }}$ is very variable, even among synaptic boutons originating from the same axon in cultured neurons (Ariel et al., 2013). More specifically, the nanoscale molecular topography of PF-PC synapses indicates that the high heterogeneity in $p_{\text {ves }}$ is because of the variable number of voltage-dependent calcium channels within close proximity to the $\mathrm{Ca}^{2+}$ sensor (Rebola et al., 2019). Moreover, this variability may be even higher if silent synapses are recruited during LTP (Jörntell and Ekerot, 2002). The small decrease in $p_{\text {ves }}$ during PF-PC LTP would indicate that new docked SVs are less efficiently coupled to $\mathrm{Ca}^{2+}$ influx than the already docked ones. PF axon terminals coexpress Munc13-1 and Munc13-3, which play a similar role in the SV cycle but with an unequal contribution to $\mathrm{P}_{\mathrm{r}}$ and RRP dynamics (Augustin et al., 2001; Chen et al., 2013). Munc13-3deficient synapses have decreased $\mathrm{P}_{\mathrm{r}}$ (Augustin et al., 2001; Ishiyama et al., 2014), and this isoform works as a developmentally upregulated mediator of tight coupling at PF-PC synapses (Kusch et al., 2018). Thus, a decrease in $p_{\text {ves }}$ during PF-PC LTP could be possible if the new docked SV s are primed by a smaller Munc13-3/Munc13-1 proportion than the previously docked SVs. Importantly, the decrease in $p_{\text {ves }}$ provoked by PF-PC LTP is compatible with an increase in the $\mathrm{P}_{\mathrm{r}}$ because the large increase in the RRP size compensates for the small decrease in $p_{\text {ves. }}$. 
In conclusion, $\beta$ ARs enhance the docking and priming of SVs through $\beta \mathrm{AR} / \mathrm{cAMP} / \mathrm{Epac}$ signaling, thereby providing a link between $\beta$ ARs and the endogenous pathways that potentiate neurotransmitter release. Hence, our findings reveal a new mechanism driven by presynaptic receptors relevant to PF-PC LTP.

\section{References}

Abbott LC, Sotelo C (2000) Ultrastructural analysis of catecholaminergic innervation in weaver and normal mouse cerebellar cortices. J Comp Neurol 426:316-329.

Alonso B, Bartolomé-Martín D, Ferrero JJ, Ramírez-Franco J, Torres M, Sánchez-Prieto J (2017) CB1 receptors down-regulate a cAMP/Epac2/ PLC pathway to silence the nerve terminals of cerebellar granule cells. J Neurochem 142:350-361.

Ariel P, Hoppa MB, Ryan TA (2013) Intrinsic variability in Pv, RRP size, Ca $(2+)$ channel repertoire, and presynaptic potentiation in individual synaptic boutons. Front Synaptic Neurosci 4:9.

Augustin I, Korte S, Rickmann M, Kretzschmar HA, Súdhof TC, Herms JW, Brose N (2001) The cerebellum-specific Munc13 isoform Munc13-3 regulates cerebellar synaptic transmission and motor learning. J Neurosci 21:10-17.

Bauer CS, Woolley RJ, Teschemacher AG, Seward EP (2007) Potentiation of exocytosis by phospholipase C-coupled G-protein-coupled receptors requires the priming protein Munc13-1. J Neurosci 27:212-219.

Bloom FE, Hoffer BJ, Siggins GR (1971) Studies on norepinephrine-containing afferents to Purkinje cells of art cerebellum. I. Localization of the fibers and their synapses. Brain Res 25:501-521.

Branco T, Staras K (2009) The probability of neurotransmitter release: variability and feedback control at single synapses. Nat Rev Neurosci 10:373383.

Carey MR, Regehr WG (2009) Noradrenergic control of associative synaptic plasticity by selective modulation of instructive signals. Neuron 62:112122.

Castillo PE, Schoch S, Schmitz F, Südhof TC, Malenka RC (2002) RIM1alpha is required for presynaptic long-term potentiation. Nature 415:327-330.

Chavez-Noriega LE, Stevens CF (1994) Increased transmitter release at excitatory synapses produced by direct activation of adenylate cyclase in rat hippocampal slices. J Neurosci 14:310-317.

Chen C, Regehr WG (1997) The mechanism of cAMP-mediated enhancement at a cerebellar synapse. J Neurosci 17:8687-8694.

Chen H, Wild C, Zhou X, Ye N, Cheng X, Zhou J (2014) Recent advances in the discovery of small molecules targeting exchange proteins directly activated by cAMP (EPAC). J Med Chem 57:3651-3665.

Chen Z, Cooper B, Kalla S, Varoqueaux F, Young SM Jr (2013) The Munc13 proteins differentially regulate readily releasable pool dynamics and calcium-dependent recovery at a central synapse. J Neurosci 33:8336-8351.

Dulubova I, Lou X, Lu J, Huryeva I, Alam A, Schneggenburger R, Südhof TC, Rizo J (2005) A Munc13/RIM/Rab3 tripartite complex: from priming to plasticity? EMBO J 24:2839-2850.

Fernandes HB, Riordan S, Nomura T, Remmers CL, Kraniotis S, Marshall JJ, Kukreja L, Vassar R, Contractor A (2015) Epac2 mediates cAMP-dependent potentiation of neurotransmission in the hippocampus. J Neurosci 35:6544-6553.

Fernández-Busnadiego R, Asano S, Oprisoreanu A-M, Sakata E, Doengi M, Kochovski Z, Zürner M, Stein V, Schoch S, Baumeister W, Lucić V (2013) Cryo-electron tomography reveals a critical role of RIM1 $\alpha$ in synaptic vesicle tethering. J Cell Biol 201:725-740.

Ferrero JJ, Alvarez AM, Ramírez-Franco J, Godino MC, Bartolomé-Martín D, Aguado C, Torres M, Luján R, Ciruela F, Sánchez-Prieto J (2013) $\beta$-Adrenergic receptors activate exchange protein directly activated by cAMP (Epac), translocate Munc13-1, and enhance the Rab3A-RIM1 $\alpha$ interaction to potentiate glutamate release at cerebrocortical nerve terminals. J Biol Chem 288:31370-31385.

Ferrero JJ, Ramírez-Franco J, Martín R, Bartolomé-Martín D, Torres M, Sánchez-Prieto J (2016) Cross-talk between metabotropic glutamate receptor 7 and beta adrenergic receptor signaling at cerebrocortical nerve terminals. Neuropharmacology 101:412-425.

Gekel I, Neher E (2008) Application of an Epac activator enhances neurotransmitter release at excitatory central synapses. J Neurosci 28:79918002.
Gioia DA, Alexander NJ, McCool BA (2016) Differential expression of Munc13-2 produces unique synaptic phenotypes in the basolateral amygdala of C57BL/6J and DBA/2J mice. J Neurosci 36:10964-10977.

Goda Y, Stevens CF (1994) Two components of transmitter release at a central synapse. Proc Natl Acad Sci U S A 91:12942-12946.

Guo A, Feng J-Y, Li J, Ding N, Li Y-J, Qiu D-L, Piao R-L, Chu C-P (2016) Effects of norepinephrine on spontaneous firing activity of cerebellar Purkinje cells in vivo in mice. Neurosci Lett 629:262-266.

Gutierrez-Castellanos N, Da Silva-Matos CM, Zhou K, Canto CB, Renner MC, Koene LMC, Ozyildirim O, Sprengel R, Kessels HW, de Zeeuw CI (2017) Motor learning requires Purkinje cell synaptic potentiation through activation of AMPA-receptor subunit GluA3. Neuron 93:409424.

Herrero I, Sánchez-Prieto J (1996) cAMP-dependent facilitation of glutamate release by beta-adrenergic receptors in cerebrocortical nerve terminals. J Biol Chem 271:30554-30560.

Huang CC, Hsu KS (2006) Presynaptic mechanism underlying cAMPinduced synaptic potentiation in medial prefrontal cortex pyramidal neurons. Mol Pharmacol 69:846-856.

Huang CC, Hsu KS, Gean PW (1996) Isoproterenol potentiates synaptic transmission primarily by enhancing presynaptic calcium channels influx via P- and/or Q-type calcium channels in the rat amygdala. J Neurosci 16:1026-1033.

Imig C, Min SW, Krinner S, Arancillo M, Rosenmund C, Südhof TC, Rhee JS, Brose N, Cooper BH (2014) The morphological and molecular nature of synaptic vesicle priming at presynaptic active zones. Neuron 84:416431.

Ishiyama S, Schmidt H, Cooper BH, Brose N, Eilers J (2014) Munc13-3 superprimes synaptic vesicles at granule cell-to-basket cell synapses in the mouse cerebellum. J Neurosci 34:14687-14696.

Ji X-H, Cao X-H, Zhang C-L, Feng Z-J, Zhang X-H, Ma L, Li B-M (2008) Pre- and postsynaptic $\beta$-adrenergic activation enhances excitatory synaptic transmission in layer V/VI pyramidal neurons of the medial prefrontal cortex of rats. Cereb Cortex 18:1506-1520.

Jörntell H, Ekerot CF (2002) Reciprocal bidirectional plasticity of parallel fiber receptive fields in cerebellar Purkinje cells and their afferent interneurons. Neuron 34:797-806.

Kaeser PS, Regehr WG (2017) The readily releasable pool of synaptic vesicles. Curr Opin Neurobiol 43:63-70.

Kaeser PS, Kwon HB, Blundell J, Chevaleyre V, Morishita W, Malenka RC, Powell CM, Castillo PE, Südhof TC (2008) RIM1alpha phosphorylation at serine- 413 by protein kinase $\mathrm{A}$ is not required for presynaptic longterm plasticity or learning. Proc Natl Acad Sci U S A 105:14680-14685.

Kaneko M, Takahashi T (2004) Presynaptic mechanism underlying cAMPdependent synaptic potentiation. J Neurosci 24:5202-5208.

Kawasaki H, Springett GM, Mochizuki N, Toki S, Nakaya M, Matsuda M, Housman DE, Graybiel AM (1998) A family of cAMP-binding proteins that directly activate Rap. Science 282:2275-2279.

Kelley GG, Reks SE, Ondrako JM, Smrcka AV (2001) Phospholipase C (epsilon): a novel Ras effector. EMBO J 20:743-754.

Kintscher M, Wozny C, Johenning FW, Schmitz D, Breustedt J (2013) Role of RIM1 $\alpha$ in short- and long-term synaptic plasticity at cerebellar parallel fibres. Nat Commun 4:2392.

Kreitzer AC, Regehr WG (2001) Retrograde inhibition of presynaptic calcium influx by endogenous cannabinoids at excitatory synapses onto Purkinje cells. Neuron 29:717-727.

Kusch V, Bornschein G, Loreth D, Bank J, Jordan J, Baur D, Watanabe M, Kulik A, Heckmann M, Eilers J, Schmidt H (2018) Munc13-3 is required for the developmental localization of $\mathrm{Ca}^{2+}$ channels to active zones and the nanopositioning of $\mathrm{Ca}_{\mathrm{v}} 2.1$ near release sensors. Cell Rep 22:19651975.

Linden DJ, Ahn S (1999) Activation of presynaptic cAMP-dependent protein kinase is required for induction of cerebellar long-term potentiation. J Neurosci 19:10221-10227.

Lippiello P, Hoxha E, Volpicelli F, Lo Duca G, Tempia F, Miniaci MC (2015) Noradrenergic modulation of parallel fiber-Purkinje cell synapse. Neuropharmacology 89:33-42.

Lonart G, Schoch S, Kaeser PS, Larkin CJ, Südhof TC, Linden DJ (2003) Phosphorylation of RIM1 $\alpha$ by PKA triggers presynaptic long-term potentiation at cerebellar parallel fiber synapses. Cell 115:49-60.

Luján R, Nusser Z, Roberts JD, Shigemoto R, Somogyi P (1996) Perisynaptic location of metabotropic glutamate receptors mGluR1 and mGluR5 on 
dendrites and dendritic spines in the rat hippocampus. Eur J Neurosci 8:1488-1500.

Ma C, Li W, Xu Y, Rizo J (2011) Munc13 mediates the transition from the closed syntaxin-Munc18 complex to the SNARE complex. Nat Struct Mol Biol 18:542-549.

Maejima T, Hashimoto K, Yoshida T, Aiba A, Kano M (2001) Presynaptic inhibition caused by retrograde signal from metabotropic glutamate to cannabinoid receptors. Neuron 31:463-475.

Martín R, Durroux T, Ciruela F, Torres M, Pin JP, Sánchez-Prieto J (2010) The metabotropic glutamate receptor mGlu7 activates phospholipase C, translocates munc-13-1 protein, and potentiates glutamate release at cerebrocortical nerve terminals. J Biol Chem 285:17907-17917.

Martín R, Ferrero JJ, Collado-Alsina A, Aguado C, Luján R, Torres M, Sánchez-Prieto J (2018) Bidirectional modulation of glutamatergic synaptic transmission by metabotropic glutamate type 7 receptors at Schaffer collateral-CA1 hippocampal synapses. J Physiol 596:921-940.

Maus L, Lee CK, Altas B, Sertel SM, Weyand K, Rizzoli SO, Rhee JS, Brose N, Imig C, Cooper BH (2020) Ultrastructural correlates of presynaptic functional heterogeneity in hippocampal synapses. Cell Rep 30:3632-3643.

Millán C, Luján R, Shigemoto R, Sánchez-Prieto J (2002) Subtype-specific expression of group III metabotropic glutamate receptors and $\mathrm{Ca} 2+$ channels in single nerve terminals. J Biol Chem 277:47796-47803.

Neher E, Brose N (2018) Dynamically primed synaptic vesicle states: key to understand synaptic short-term plasticity. Neuron 100:1283-1291.

Ozaki N, Shibasaki T, Kashima Y, Miki T, Takahashi K, Ueno H, Sunaga Y, Yano H, Matsuura Y, Iwanaga T, Takai Y, Seino S (2000) cAMP-GEFII is a direct target of cAMP in regulated exocytosis. Nat Cell Biol 2:805-811.

Parfitt KD, Doze VA, Madison DV, Browning MD (1992) Isoproterenol increases the phosphorylation of the synapsins and increases synaptic transmission in dentate gyrus, but not in area CA1, of the hippocampus. Hippocampus 2:59-64.

Ramírez-Franco J, Bartolomé-Martín D, Alonso B, Torres M, Sánchez-Prieto J (2014) Cannabinoid type 1 receptors transiently silence glutamatergic nerve terminals of cultured cerebellar granule cells. PLoS One 9:e88594.

Rebola N, Reva M, Kirizs T, Szoboszlay M, Lörincz A, Moneron G, Nusser Z, DiGregorio DA (2019) Distinct nanoscale calcium channel and synaptic vesicle topographies contribute to the diversity of synaptic function. Neuron 104:693-710.

Rhee JS, Betz A, Pyott S, Reim K, Varoqueaux F, Augustin I, Hesse D, Südhof TC, Takahashi M, Rosenmund C, Brose N (2002) $\beta$ phorbol ester- and diacylglycerol-induced augmentation of transmitter release is mediated by Munc13s and not by PKCs. Cell 108:121-133.

Rosenmund C, Stevens CF (1996) Definition of the readily releasable pool of vesicles at hippocampal synapses. Neuron 16:1197-1207.

Sadana R, Dessauer C (2009) Physiological roles for G protein-regulated adenylyl cyclase isoform: insights from knockout and overexpression studies. Neurosignals 17:5-22.

Safo PK, Regehr WG (2005) Endocannabinoids control the induction of cerebellar LTD. Neuron 48:647-659.

Sakaba T, Neher E (2001) Preferential potentiation of fast-releasing synaptic vesicles by cAMP at the calyx of Held. Proc Natl Acad Sci U S A 98:331336.

Sakaba T, Neher E (2003) Direct modulation of synaptic vesicle priming by GABA(B) receptor activation at a glutamatergic synapse. Nature 424: 775-778.

Sakamoto H, Ariyoshi T, Kimpara N, Sugao K, Taiko I, Takikawa K, Asanuma D, Namiki S, Hirose K (2018) Synaptic weight set by Munc13-1 supramolecular assemblies. Nat Neurosci 21:41-49.

Salin PA, Malenka RC, Nicoll RA (1996) Cyclic AMP mediates a presynaptic form of LTP at cerebellar parallel fiber synapses. Neuron 16:797-803.
Schikorski T, Stevens CF (2001) Morphological correlates of functionally defined synaptic vesicle populations. Nat Neurosci 4:391-395.

Schmidt M, Evellin S, Weernink PA, von Dorp F, Rehmann H, Lomasney JW, Jakobs KH (2001) A new phospholipase-C-calcium signalling pathway mediated by cyclic AMP and a Rap GTPase. Nat Cell Biol 3:10201024.

Schneggenburger R, Meyer AC, Neher E (1999) Released fraction and total size of a pool of immediately available transmitter quanta at a calyx synapse. Neuron 23:399-409.

Shibasaki T, Takahashi H, Miki T, Sunaga Y, Matsumura K, Yamanaka M, Zhang C, Tamamoto A, Satoh T, Miyazaki J-I, Seino S (2007) Essential role of Epac/Rap1 signaling in regulation of insulin granule dynamics by cAMP. Proc Natl Acad Sci U S A 104:19333-19338.

Storm DR, Hansel C, Hacker B, Parent A, Linden DJ (1998) Impaired cerebellar long-term potentiation in type I adenylyl cyclase mutant mice. Neuron 20:1199-1210.

Thomas GM, Geny B, Cockcroft S (1991) Identification of a novel cytosolic polyphosphoinositide-specific phospholipase C (PLC-86) as the major Gprotein regulated enzyme. EMBO J 10:2507-2512.

Tong J, Liu X, Vickstrom C, Li Y, Yu L, Lu Y, Smrcka AV, Liu QS (2017) The Epac-phospholipase $\mathrm{C} \varepsilon$ pathway regulates endocannabinoid signaling and cocaine-induced disinhibition of ventral tegmental area dopamine neurons. J Neurosci 37:3030-3044.

Tsalkova T, Mei FC, Li S, Chepurny OG, Leech CA, Liu T, Holz GG, Woods VL Jr, Cheng X (2012) Isoform-specific antagonists of exchange proteins directly activated by cAMP. Proc Natl Acad Sci U S A 109:18613-18618.

Ul Haq R, Anderson M, Liotta A, Shafiq M, Sherkheli MA, Heinemann U (2016) Pretreatment with $\beta$-adrenergic receptor agonists facilitates induction of LTP and sharp wave ripple complexes in rodent hippocampus. Hippocampus 26:1486-1492.

Villacres EC, Wong ST, Chavkin C, Storm DR (1998) Type I adenylyl cyclase mutant mice have impaired mossy fiber long-term potentiation. J Neurosci 18:3186-3194.

Wayman GA, Impey S, Wu Z, Kindsvogel W, Prichard L, Storm DR (1994) Synergistic activation of the wild type adenylyl cyclase by $\mathrm{Ca}^{2+}$ by Gscoupled receptors in vivo. J Biol Chem 269:25400-25405.

Wójtowicz AM, Fidzinski P, Heinemann U, Behr J (2010) Beta-adrenergic receptor activation induces long-lasting potentiation in burst-spiking but not regular-spiking cells at CA1 subiculum synapses. Neuroscience 171:367-372.

Xu-Friedman MA, Regehr WG (1999) Presynaptic strontium dynamics and synaptic transmission. Biophys J 76:2029-2042.

Yang Y, Shu X, Liu D, Shang Y, Wu Y, Pei L, Xu X, Tian Q, Zhang J, Qian K, Wang YX, Petralia RS, Tu W, Zhu LQ, Wang JZ, Lu Y (2012) EPAC null mutation impairs learning and social interactions via aberrant regulation of miR-124 and Zif268 translation. Neuron 73:774-788.

Yao L, Sakaba T (2010) cAMP modulates intracellular Ca2+ sensitivity of fast-releasing synaptic vesicles at the calyx of Held synapse. J Neurophysiol 104:3250-3260

Yawo H (1996) Noradrenaline modulates neurotransmitter release by enhancing the $\mathrm{Ca} 2+$ sensitivity of exocytosis in the chick ciliary presynaptic terminal. J Physiol 493:385-391.

Yawo H (1999) Involvement of cGMP-dependent protein kinase in adrenergic potentiation of transmitter release from the Calyx-type presynaptic terminal. J Neurosci 19:5293-5300.

Zieba BJ, Artamonov MV, Jin L, Momotani K, Ho R, Franke AS, Neppl RL, Stevenson AS, Khromov AS, Chrzanowska-Wodnicka M, Somlyo AV (2011) The cAMP-responsive Rap1 guanine nucleotide exchange factor, Epac, induces smooth muscle relaxation by down-regulation of RhoA activity. J Biol Chem 286:16681-16692. 